Article

\title{
The Impact of Reforestation Induced Land Cover Change (1990-2017) on Flood Peak Discharge Using HEC-HMS Hydrological Model and Satellite Observations: A Study in Two Mountain Basins, China
}

\author{
Crispin Kabeja ${ }^{1,2}$, Rui $\mathrm{Li}^{1, *}{ }^{1}$, Jianping Guo ${ }^{3}{ }^{-}$, Digne Edmond Rwabuhungu Rwatangabo ${ }^{2}{ }^{-}$, \\ Marc Manyifika $\left.{ }^{4} \mathbb{(}\right)$, Zongting Gao ${ }^{5} \mathbb{D}$, Yipu Wang ${ }^{1} \mathbb{D}$ and Yuxiang Zhang ${ }^{1}$ \\ 1 School of Earth and Space Sciences, Chinese Academy of Sciences Center for Excellence in Comparative \\ Planetology, University of Science and Technology of China, 96 Jinzhai Road, Hefei 230026, China; \\ kabejacrispin@mail.ustc.edu.cn (C.K.); wypustc@mail.ustc.edu.cn (Y.W.); zyx2012@mail.ustc.edu.cn (Y.Z.) \\ 2 School of Mining and Geology, College of Science and Technology, University of Rwanda, \\ PO Box 4285 Kigali, Rwanda; drwabuhu@gmail.com \\ 3 State Key Laboratory of Severe Weather, Chinese Academy of Meteorological Sciences, Beijing 100081, China; \\ jpguo@cma.gov.cn \\ 4 Faculty of Geo-Information Science and Earth Observation (ITC), University of Twente, PO Box 217, \\ 7500 AE Enschede, The Netherlands; marc.manyifika@gmail.com \\ 5 Institute of Meteorological Sciences of Jilin Province, Jilin Provincial Key Laboratory of Changbai Mountain \\ Meteorology \& Climate Change, Laboratory of Research for Middle-High Latitude Circulation and East \\ Asian Monsoon, Changchun 130062, China; ztgtq@sina.com \\ * Correspondence: rli7@ustc.edu.cn; Tel.: +86-551-6360-0027
}

Received: 19 March 2020; Accepted: 5 May 2020; Published: 9 May 2020

\begin{abstract}
Understanding the effect of land use and land cover (LULC) type change on watershed hydrological response is essential for adopting applicable measures to control floods. In China, the Grain to Green Program (GTGP) and the Natural Forest Conservation Program (NFCP) have had a substantial impact on LULC. We investigate the effect of these conservation efforts on flood peak discharge in two mountainous catchments. We used a series of Landsat images ranging from 1990 to 2016/2017 to evaluate the LULC changes. Further to this, the hydrological responses at the basin and sub-basin scale were generated by the Hydrologic Modeling System (HEC-HMS) under four LULC scenarios. Between 1990 and 2016/2017, both catchments experienced an increase in forest and urban land by $18 \%$ and $2 \%$ in Yanhe and by $16 \%$ and $8 \%$ in Guangyuan, respectively. In contrast, the agricultural land decreased by approximately $30 \%$ in Yanhe and $24 \%$ in Guangyuan, respectively. The changes in land cover resulted in decrease in flood peak discharge ranging from $14 \%$ in Yanhe to $6 \%$ in Guangyuan. These findings provide a better understanding on the impact of reforestation induced LULC change on spatial patterns of typical hydrological responses of mountainous catchment and could help to mitigate flash flood hazards in other mountainous regions.
\end{abstract}

Keywords: land use/cover change; Grain to Green Program (GTGP); HEC-HMS model; flash flood peak discharge; mountainous catchments

\section{Introduction}

Globally, flash floods are the most frequent and devastating natural disaster that pose a significant threat to human life and cause damage to the economy [1-4]. Modrick and Georgakakos [5] defined flash 
floods as an event where streamflow increases and decreases fast without warning as a result of severe rainfall. LULC and climate changes can affect catchments' hydrologic processes and cause changes in flash flood frequencies [6]. For example, changes in LULC as a result of various anthropogenic activities alter the catchment's characteristics and aggravate the fast hydrological responses to result in destructive floods in low-lying areas [7]. Moreover, flash floods are likely to occur in mountainous catchments of a few hundred square kilometers or less, where intense rainfall is converted into runoff from upper stream areas [8,9].

In China, floods have caused loss of life and infrastructure damages in mountainous and hilly areas [10]. Studies [11,12] showed that between 2006 and 2015, flood disasters caused the death of 6641 people and affected half a billion other people in China. Additionally, they provoked more than $\$ 87.5$ billion USD in economic loss. For example, the flash flood that hit the capital city of China, Beijing, in 2012, caused the death of 77 people, with an estimated economic loss of US \$1.6 billion. Some other studies [13] showed that 641 Chinese regions and cities are likely to be affected by floods. Furthermore, Miao et al. [14] observed that most of the flash floods in China occur regularly in mountainous catchments with poor vegetation cover.

The Chinese government introduced policies and other initiatives to reduce the impact of flooding. For example, the Natural Forest Conservation Program (NFCP) and Grain to Green Program (GTGP), which are the two main wide programs of reforestation and afforestation, were introduced with the aim of reducing flash floods and erosion in many regions [15,16]. Other measures such as forecasting and warning systems and sustainable land use (e.g., green spaces) for flood mitigation were introduced in various regions [17]. For instance, vegetation and green spaces have various functions on catchment hydrology, including reducing flash floods, as they serve as barriers to surface runoff [18]. Several studies $[19,20]$ demonstrated that the GTGP and NFCP conservation policies influenced the land use/cover changes in various regions in China. However, few studies investigated the effect of these two policies on catchment hydrological response in mountainous regions of China.

In the past decades, some authors showed that the decrease in forest covers was the main cause of the increase in surface runoff as well as flooding [21-23]. Other studies [24,25] attributed the increase in runoff and peak flows to both climate and land use changes. However, Liu et al. [26] and Chu et al. [27] argued that the change in land use only causes a slight change in runoff and streamflow. Alkama et al. [28] also found no strong correlation between changes of land use types and runoff generation. Wilk et al. [29] demonstrated that the alternations in land use/cover are insignificant to the hydrological response in larger watershed because surface runoff takes place at a small part of the watershed area, which causes a slight change in peak discharge. Moreover, Cavalcante et al. [30] pointed out that it may be difficult to understand the hydrological response of land use changes in large-scale basins that have a mixture of land use classes in different phases of protection and regeneration. The aforementioned studies showed that the relationships between changes in land cover and catchment hydrological response remain a controversial topic and will be constantly researched in the future.

A limited amount of research has assessed the effectiveness of the NFCP and GTGP in reducing flash flood and erosion in mountainous regions in China [31,32]. Yang et al. [33] and Zhao et al. [34] assessed the impact of GTGP on vegetation cover change and soil erosion in the Loess Plateau and noted a decrease in soil erosion. Zhang et al. [35] observed a reduction in soil erosion in most southern regions of China as result of land cover change induced by GTGP and NFCP. On the contrary, Xie et al. [36] found that the change in land cover caused by afforestation activities in China's Three-North region had insignificant effects on hydrological cycle. Most of these studies are inconsistent concerning the impact of land cover changes on catchment hydrological response in various regions in China.

More important, some of these studies were focused on the relationship between vegetation cover changes and soil erosion in non-mountainous regions and mostly using statistical methods and on short timescales. Therefore, there is a need to extend previous studies to mountain area and conduct quantitative analysis based on long historical data and hydrological modeling. 
The goal of the present study is to investigate the effect of alternation in land cover induced by the NFCP and GTGP on flash flood peak discharge in two medium-sized (500-8000 km²) mountainous watersheds in China. This study does not consider the impact of climate change. In summary, it attempts to address the following specific objectives: (1) to quantify the changes in land use land cover induced by NFCP and GTGP in the two catchments; (2) to investigate the temporal evolution of flash flood peak discharge with diverse historical land cover changes using the HEC-HMS hydrological model; (3) to analyze the spatiotemporal trends of peak discharge and vegetation index at the sub-basin scale. The results of this study will improve our understanding of how changes in land cover affect catchment hydrological response and serve as a reference formulating mitigation strategies to prevent future flash floods disaster in mountainous regions.

\section{Data and Research Methods}

\subsection{Study Area}

The present study was carried out in two mountainous catchments with different size and climate conditions, located in China. The two catchments have undergone changes in land cover at different degrees in the last 25 years, and hence, serve as ideal sites to evaluate the impact of reforestation induced land use land cover change on flash flood peak discharge. The first study area is the Yanhe catchment, and is located in the middle regions of Loess Plateau, in the northern Shaanxi province in China $\left(36^{\circ} 21^{\prime}-37^{\circ} 19^{\prime} \mathrm{N} ; 108^{\circ} 38^{\prime}-110^{\circ} 29^{\prime}\right.$ E) (Figure 1c). The catchment covers an area of $7724 \mathrm{~km}^{2}$ with an altitude range from 484 to $1797 \mathrm{~m}$ above sea level. It is characterized by a steep gullies region and has a warm temperate continental semi-arid monsoon climate. The Yanhe catchment has an average annual precipitation of $495 \mathrm{~mm}$ with over $70 \%$ falls in the summer (June-September) and average annual temperature varies from 8.8 to $10.2^{\circ} \mathrm{C}$. The main land use types are grassland, forest and agricultural land. This study catchment is affected by soil erosion and floods, and is among the regions where the Chinese government introduced many land use conservation programs [12].

The second study area is the Guangyuan catchment, one of the Sichuan basin tributaries and is located in the Southwest of China $\left(32^{\circ} 16^{\prime}-32^{\circ} 35^{\prime} \mathrm{N} ; 105^{\circ} 50^{\prime}-106^{\circ} 11^{\prime} \mathrm{E}\right)$ (Figure 1d). This study catchment has a drainage area of $578 \mathrm{~km}^{2}$. The elevation of the catchment ranges from 800 to $1400 \mathrm{~m}$ above sea level and the slopes range from $0 \%$ to $44 \%$, respectively. The catchment has a subtropical monsoon climate with an annual rainfall that ranges between 1200 to $1600 \mathrm{~mm}$. Land use is dominated by forest and agriculture. Urban areas are found mainly in low laying areas in proximity to the main river. The catchment is located in the region that was selected for forest cover expansion under various conservation programs such as GTGP and NFCP. Moreover, it has experienced various floods in the past that have resulted in various types of disasters such as loss of human lives and economic losses [37]. Hence, the Guangyuan catchment serves as an ideal site to evaluate the impact of reforestation induced land use land cover change on flood peak discharge.

\subsection{Sources of Data}

The dataset used in this study includes the satellite images data from the Landsat 5 Thematic Mapper (TM) and Landsat 8 Operational Land Imager (OLI) for the years 1990, 2000, 2002, 2008, 2010, 2016 and 2017. Both Landsat sensors have the same spatial resolution of $30 \mathrm{~m}$ and cover each of our study area. The free available geometrically corrected Landsat L1T data were downloaded (http://www.earthexplorer.usgs.gov) and used in the present study. We selected clear satellite images with less than $10 \%$ cloud and cloud shadows. The Landsat images from the same season of the year and with close time of acquisition by the sensors were selected. This facilitated in comparing Landsat images of different periods. We also used land use maps of China (http://www.resdc.cn) for validation of the Landsat images. The soil data of the two study catchments (soil type and texture) were downloaded from the world soil database (http://www.fao.org/data/en/) [38]. The hourly rainfall data (2002-2011) were provided by the China Meteorological Administration and were collected from 
various meteorological stations located inside each study catchment and within a maximum distance of $10 \mathrm{~km}$ from the basin perimeter (Figure 1). The daily discharge data (2000-2012) of the Yanhe catchment were acquired from the Yellow River Conservancy Commission (YRCC) and used for model calibration and validation. Lastly, the Digital Elevation Model (DEM) with a spatial resolution of $30 \mathrm{~m}$ from the Shuttle Radar Topography Mission (SRTM) was accessed from the United States Geological Survey website.

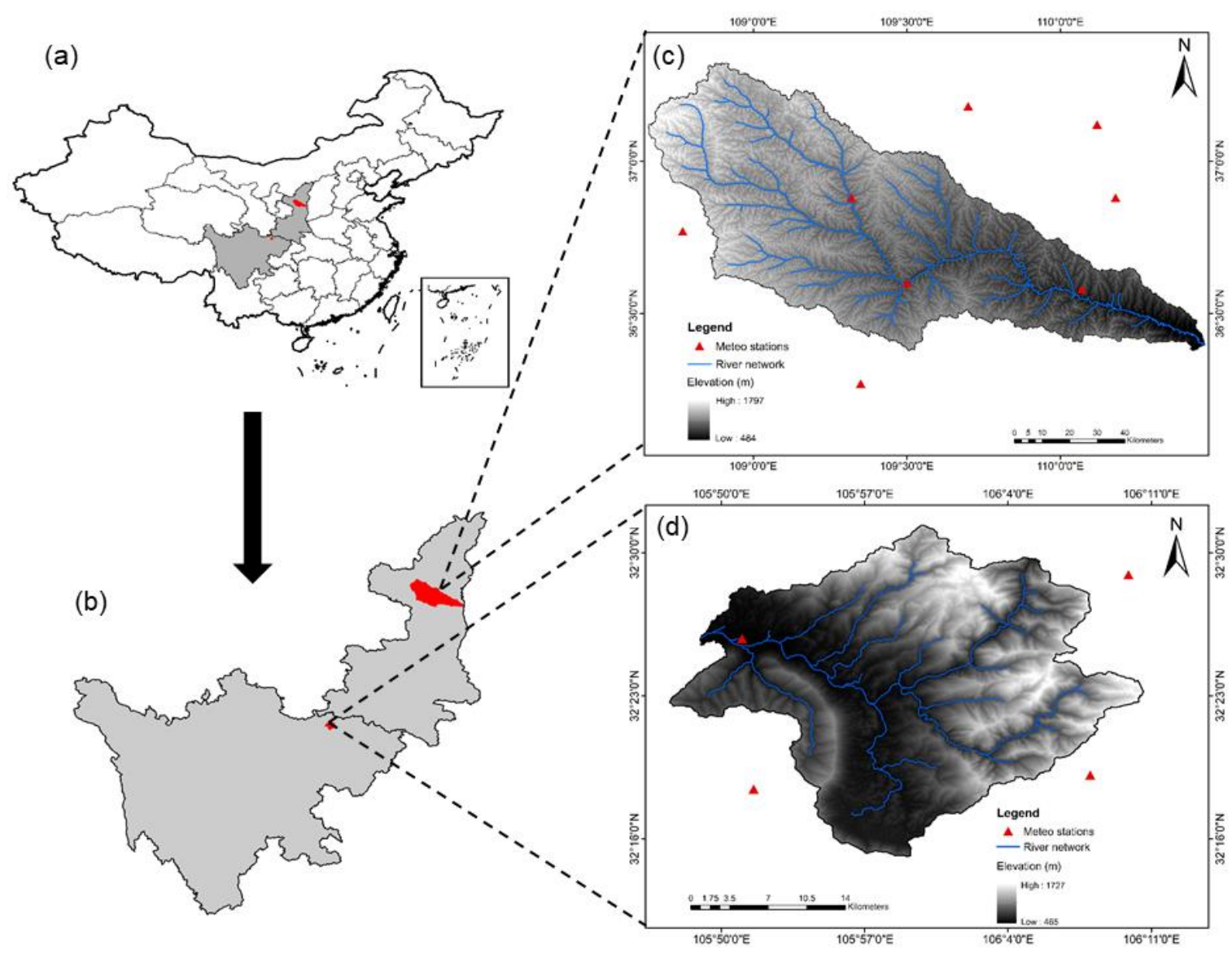

Figure 1. The location of the two study catchments used in this study in China (a), location of study area catchments in Shaanxi and Sichuan provinces (b), respectively, the Yanhe (c) and Guangyuan (d) study area boundary; elevation with the stream network is shown with blue solid lines and red triangles represent meteorological stations.

\subsection{Satellite Image Processing and Land Use Land Cover Classification}

The atmospheric effect removed Landsat reflectance images were used in this study. The supervised image classification method was used [39] to perform land use land cover classification. High-resolution imagery from Google Earth pro served as the reference map for training during Landsat image classification. Additionally, other information from China land use maps (2000, 2005, 2010 and 2015 accessible at http://www.resdc.cn) related to the land cover pattern of the two study areas were taken into consideration during on-screen training sample selection. Google Earth pro provides a tool to access historical high-resolution imagery of the area of interest with dates similar or close to that of the Landsat images [40]. In our case, all the imagery covering both study catchments were available in Google Earth pro. Other studies [41,42] also demonstrated that Google Earth is a reliable source for selecting training samples in satellite image classification.

We selected randomly 20 training samples per land cover class [43] and used the Maximum Likelihood Classifier (MLC) algorithm of supervised classification for land cover classification of each 
Landsat image. The MLC algorithm is a robust and optimal classifier and is the most used algorithm in the assessment of land cover changes that produces high accurate results [44]. Therefore, we used the training samples for selecting representative classes for each category with the aim of defining various spectral signatures. From the spectral signature, each pixel in the Landsat satellite image was assigned to the appropriate class [45]. Finally, all LULC types were identified and classified into five land cover classes (agriculture, grassland, forest, urban and water bodies), named based on the nomenclature developed by the Chinese Academy of Science (CAS) [46]. Then, based on the Normalized Difference Vegetation Index (NDVI), we reassessed the misclassified pixels from the initial classification and reclassified accordingly. The isolated pixels in each classified image were removed by applying the majority spatial filters [47]. The classified maps showed satisfactory results for the overall classification accuracies of $87 \%$ and $91 \%$ and Kappa coefficients of 0.86 and 0.89 , (1 represents the best classification [48]) for the Yanhe and Guangyuan catchments, respectively. The accuracy assessment results were satisfactory following the standard suggested by Anderson [45] for Landsat image classification.

\subsection{Land Use Land Cover Change and Vegetation Analysis}

According to Lu et al. [49], assessing the LULC change requires the analysis of satellite images representing the same area taken at different times. Therefore, to allow comparison and detect any changes in our study areas across selected years, the classified Landsat images were analyzed. We quantified all classified LULC maps by using the post classification change extraction method [50,51]. Therefore, the statistical information and area $\left(\right.$ in $\mathrm{km}^{2}$ ) of each LULC class from the classified maps were computed to generate a change matrix. The similar classes structure used during the classification of Landsat images simplified the computation. Furthermore, the spatial analysis tools in ArcGIS 10.3 were used to better visualize the observed trends in land cover change in the two study catchments.

Vegetation plays a crucial role in flash flood control and regulation because areas with dense vegetation and forest diminish surface runoff [52-55]. In this study, the vegetation distribution and status in the study catchments in various historical periods was analyzed using the normalized difference vegetation index (NDVI). We calculated the NDVI values from the surface reflectance Landsat images as shown in Equation (1) [56]. The NDVI maps were compared to assess vegetation changes in each year. Moreover, the NDVI maps were used to validate the classified LULC maps.

$$
\mathrm{NDVI}=\frac{\rho \mathrm{NIR}-\rho \mathrm{RED}}{\rho \mathrm{NIR}+\rho \mathrm{RED}}
$$

where $\rho$ NIR is the near infrared band and $\rho$ RED is the red band.

\subsection{Hydrological Modeling Using HEC-GeoHMS and HEC-HMS}

The Hydrologic Engineering Center Hydrologic Modeling System (HEC-HMS) is an event-based hydrological model and was developed to simulate the hydrological processes of various types of catchments in different areas of research, including watershed runoff studies, flood damage studies through the analysis of hydrography, floodplain management etc., [57]. The model consists of four modules for event simulation including basin and meteorological modules, time series data, and control specifications. The basin model includes processes such as basin and river routing while the meteorological model includes rainfall data. The control specifications are used for timing processes of the model. After integration of all the required data, the HEC-HMS applies all the models to simulate the hydrological process. The outcome of the HEC-HMS model is the hydrograph at the catchment outlet. More details on the model functionality of the HEC-HMS model are provided in the user and technical references [57,58]. Sanyal et al. [59] suggested the use of the HEC-HMS model in a data scarce situation as the main inputs data to run the model can be obtained through remote sensing means. Considering that there are no sufficient ground data in our two study catchments, we selected HEC-HMS version 4.2.1 to quantify the impact of land cover changes on flash flood 
peak discharge, based on the application of suitable loss, transform and routing methods. All the main input data required to run the HEC-HMS model are prepared in the HEC-GeoHMS model. The HEC-GeoHMS model is an extension of Arc GIS software. The units of the HEC-HMS model are provided in detail below.

\subsubsection{The Basin Model}

The main input data required to run the HEC-HMS Model were the Digital Elevation Model (DEM), land cover maps, soil map and rainfall data [58] (Figure 2). The basin model incorporates the data relevant to the physical attributes of the HEC-HMS model. We used HEC-GeoHMS, an extension in the ArcGIS environment, to delineate the study catchments from DEM. Through a number of processing steps, known as the terrain processing to the DEM, we derived the streams network and subdivide our study catchments into interconnected sub-basins. In addition, other catchment characteristics such as elevation, slope, stream length and the area of each sub-catchment were obtained. The hydrologic elements of the basin model for the two catchments are presented in Figure 3.

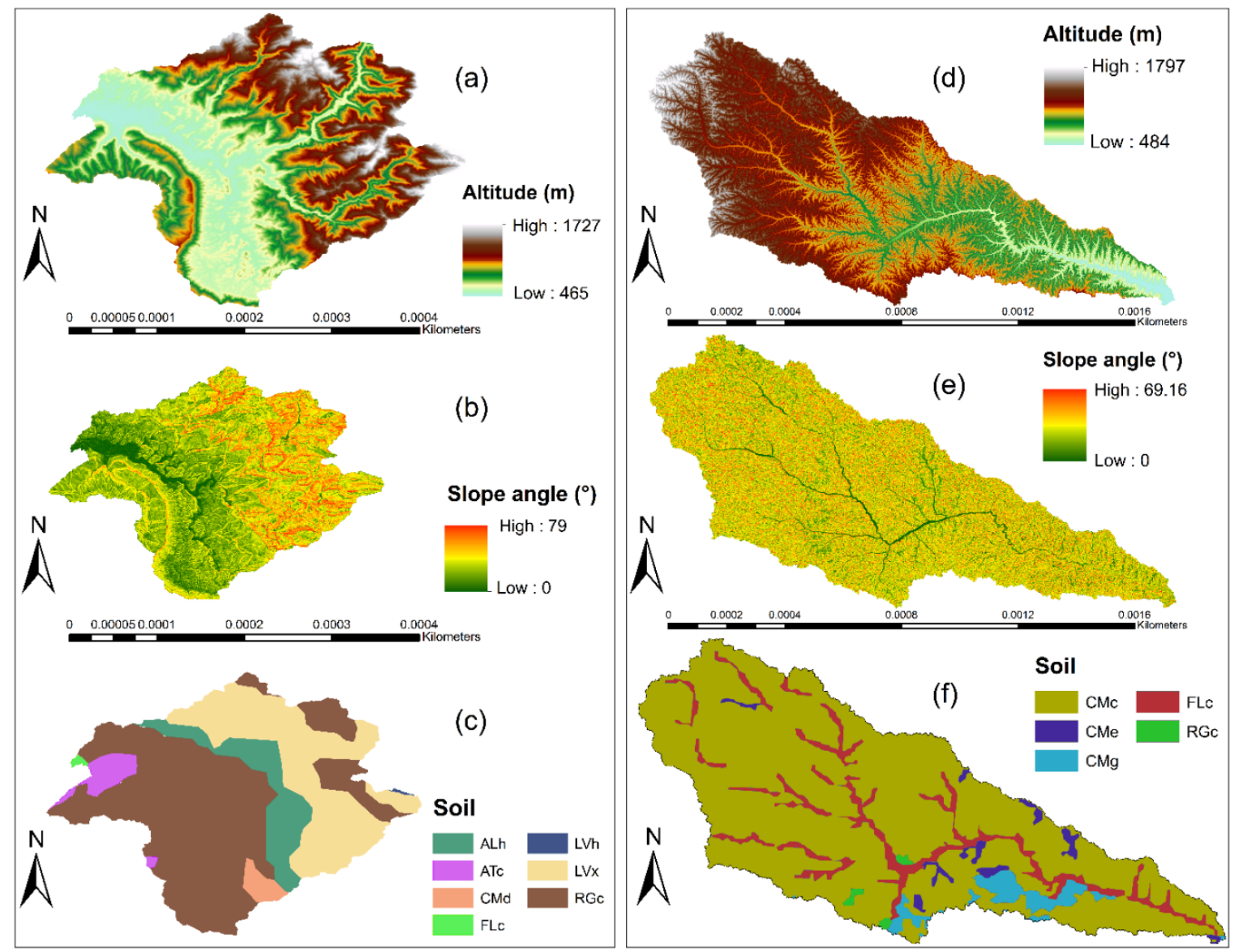

Figure 2. Model input thematic layers: Altitude (a,d), Slope angle (b,e) and Soil type (c,f) for Guangyuan and Yanhe (Soil types: ALh: Haplic Alisols; ATc: Cumulic Anthrosols; CMd: Dystric Cambisols; FLc: Calcaric Fluvisols; LVh: Haplic Luvisols; LVx: Chromic Luvisols; RGc: Calcaric Regosols; CMc: Calcaric Cambisols; CMe: Eutric Cambisols; CMg: Gleyic Cambisols). 

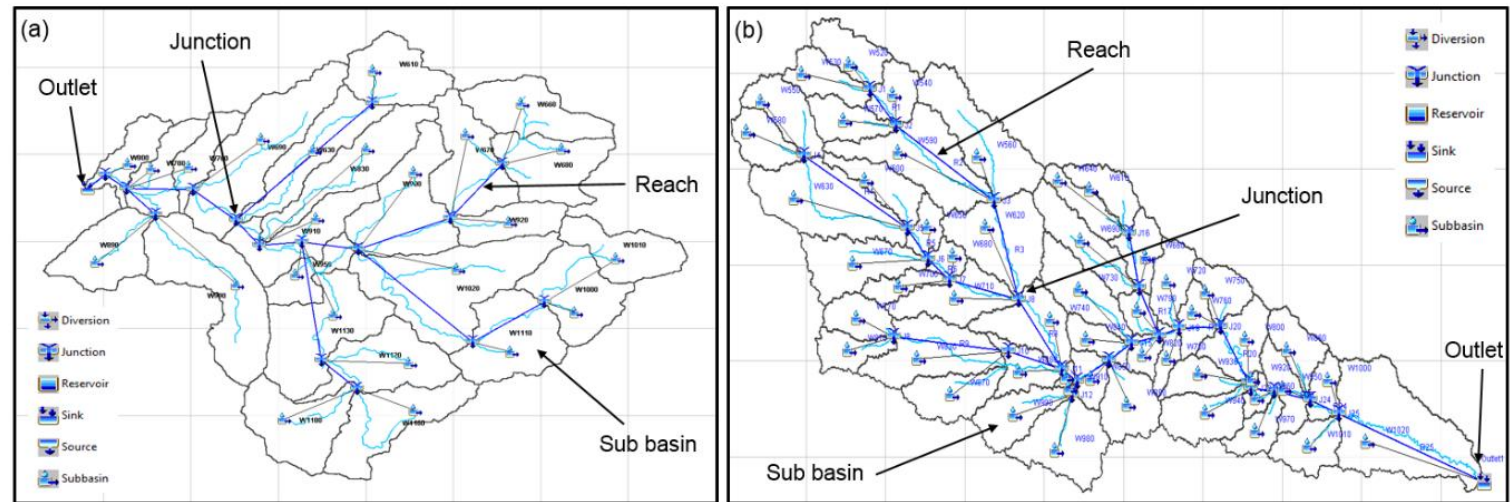

Figure 3. Sketch map of the HEC-HMS model for the Guangyuan (a), and Yanhe (b) watersheds.

\subsubsection{Meteorological Model}

The rainfall data are an essential input during simulation of flash flood event using hydrological models, as high intensity rainfall falling for a few hours may cause flooding [60]. In the HEC-HMS model, the rainfall data are required to set up the meteorological model and are one of the main inputs to run the model. In this study, we examined rainfall data at hourly temporal resolution during 2002 to 2011 and selected the largest rainstorm events that caused flash floods in each study catchment. For the Yanhe catchment, we selected intense rainfall events from the 18-22 August 2010 for the model simulation. Similarly, for the Guangyuan catchment, the rainfall events that took place on 22-25 August 2010 were given as input in the model. The distribution of these rainfall events in the catchment was calculated using the kriging interpolation method [61] based on the rainfall values collected at rain gauging stations located in each studied catchment.

\subsubsection{The HEC-HMS Model Control Specifications}

The model control specifications incorporate data related to the timing of the HEC-HMS model such as the time steps, start and end date, and simulation time adopted in the model. In the present study, the time steps were set to $1 \mathrm{~h}$ and were selected based on the computed shortest lag times of the small sub-basin in the HEC-HMS model [58].

\subsubsection{Curve Number Loss Method}

To calculate the rainfall losses occurring in the catchment, we selected the soil conservation service (SCS) curve number (CN) loss method [62]. The SCS-CN method is extensively used in ungauged watershed because of minimal data requirements [63]. It uses the $\mathrm{CN}$ parameter, which reflects land features such as LULC and soil type characteristics of the two study catchments. It has been successful in simulating hydrological processes in many regions $[59,64]$. The SCS-CN method uses $\mathrm{CN}$ values for each sub-basin and the initial abstraction values. The low $\mathrm{CN}$ value signifies higher infiltration losses while the higher $\mathrm{CN}$ correspond to less infiltration losses. Thus, the ground surface with a higher $\mathrm{CN}$ value is more likely to generate higher runoff yield and cause floods. Equation (2) presents the calculation of loss using SCS-CN method [62].

$$
\mathrm{Q}=\frac{(\mathrm{P}-\mathrm{Ia})^{2}}{(\mathrm{P}-\mathrm{Ia})+\mathrm{S}}
$$

where $\mathrm{Q}$ is the accumulated direct runoff depth, $\mathrm{P}$ is accumulated storm rainfall, Ia is the initial abstraction (initial loss) and is given by $0.2 S$, and $S$ is the potential maximum retention and is a measure 
of the capability of a catchment to absorb and retain storm rainfall. The potential maximum retention (S) is related to the curve number $(\mathrm{CN})$ by the following equation (Equation (3)):

$$
S=\frac{25400-254 \mathrm{CN}}{\mathrm{CN}}
$$

where $\mathrm{CN}$ is the soil conservation service (SCS) curve number $(\mathrm{CN})$, the SCS-CN is an index that illustrates the combination of soil hydrologic group, LULC classes, and antecedent soil moisture conditions.

We generated the parameter $\mathrm{CN}$ by combining the hydrologic soil groups (HSG) and land use/cover maps of each studied catchment in different periods. The HSG data were prepared using the soil data of each studied that contained all the information related to soil texture and soil types of each of the study catchment. The HSG categorizes soil classes into four groups (A, B, C and D), where soils in group A has high infiltration potential and soils in group D has low infiltration rate [58]. We referred to the $\mathrm{CN}$ table defined by the USDA [58] to generate the $\mathrm{CN}$ maps of each catchment. The cover type was determined by comparing cover type as named in the $\mathrm{CN}$ table to the LULC type in each studied catchment (Table 1). The obtained $\mathrm{CN}$ maps show the physical parameters in each catchment and were used as input during model simulation by HEC-HMS.

Table 1. The CN values of LULC types and hydrologic soil group used in the present study.

\begin{tabular}{ccccc}
\hline \multirow{2}{*}{ LULC Type } & \multicolumn{4}{c}{ Curve Numbers for Hydrologic Soil Group } \\
\cline { 2 - 5 } & A & B & C & D \\
\hline Agriculture & 67 & 78 & 85 & 89 \\
Urban & 77 & 85 & 90 & 92 \\
Grassland & 39 & 61 & 74 & 80 \\
Forest & 32 & 58 & 72 & 79 \\
Water & 98 & 98 & 98 & 98 \\
\hline
\end{tabular}

\subsubsection{Soil Conservation Service (SCS) Unit Hydrograph Method}

In this study, we used the SCS unit hydrograph method to convert the excess rainfall into a flow hydrograph at the catchment outlet [65]. The basin lag time and time of concentration (Tc) are the main input parameters. The basin lag time was calculated for each sub-basin using the curve number values and sub-basin slope length, whereas the Tc was estimated based on sub-basin characteristics (e.g., topography) and reach length in the HEC-GeoHMS software environment.

\subsubsection{Routing Method}

The routing method accounts for the route the runoff through the channel reaches to the outlet of the catchment and generates a flow hydrograph [64]. In this study, we used the Muskingum-Cunge routing method, which uses two parameters $\mathrm{K}$ and $\mathrm{X}$. The travel time $\mathrm{K}$ simulates a delay in runoff as it passes through the channel whereas the degree of storage values $X$ (assumed to be 0.2 ) is used to regulate the influence of inflow and outflow hydrograph [58].

\subsubsection{Simulated Land Use Land Cover Change Scenarios}

To evaluate and understand the effect of the two conservation policies (NFCP and GTGP) on flood peak discharge, we set up four scenarios of LULC for each studied catchment. These LULC scenarios represent the land cover conditions from 1990 to 2016 for the Yanhe catchment and from 1990 to 2017 for the Guangyuan catchment, respectively. For example, the first scenario was performed using the 1990 LULC map and was considered as the baseline scenario (S1). Similarly, the second (S2), the third (S3) and the fourth (S4) scenarios were established based on other historical LULC maps [66]. The land cover change rate and the change of land cover area (in $\mathrm{km}^{2}$ ) under these four scenarios in the two catchments are presented in Figure 4. For each catchment, we conducted four hydrological simulations 
(S1, S2, S3 and S4) using the HEC-HMS hydrological model while keeping constant other model input parameters that describe the catchment characteristics and boundary conditions, hence, to observe and compare the changes in flood peak discharge in each historical time period due to the isolated impact of LULC changes alone $[67,68]$.
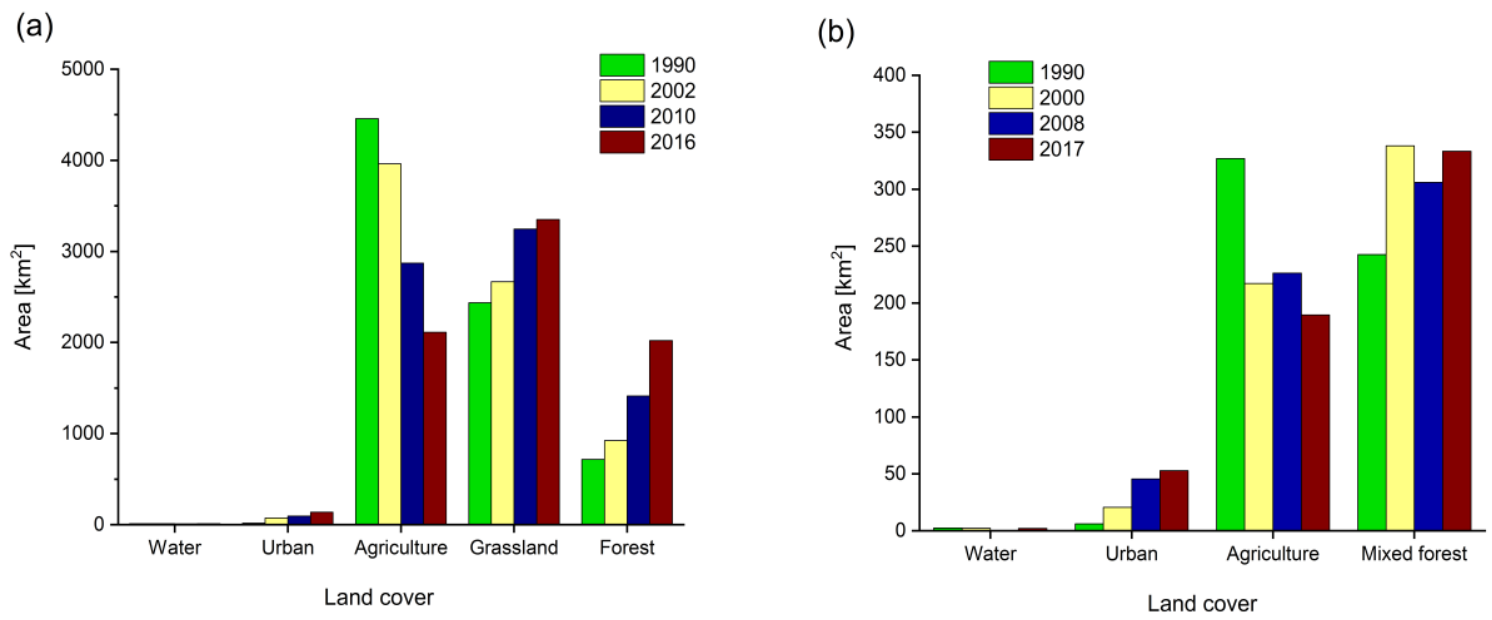

Figure 4. Area covered by each LULC class over 1990-2016/2017 for the Yanhe (a) and Guangyuan (b) watersheds.

Following the argument of Wilk and Hughes [69], we assessed the impact of changed vegetation cover on flood peak discharge at the sub-basin scale in each study catchment. This was done by comparing the model outputs of the baseline scenario S1 to that of scenario S4 in the four sub-basins that have undergone significant changes in land cover and examine any change in peak discharge during our study period. Moreover, we analyzed the spatial NDVI changes in each sub-basin and compared them to changes in peak discharge.

\section{Results and Discussion}

\subsection{Land Use Land Cover Classification and Change Detection Analysis}

The LULC classified maps for both the Yanhe and Guangyuan catchments are presented in Figures 5 and 6, and the corresponding detailed changes in land cover types (in \%) were analyzed and quantified as compiled in Tables 2 and 3, respectively. Both studied sites have undergone extensive land cover changes due to NFCP and GTGP conservation programs.

The LULC changes in the Yanhe catchment were investigated from 1990 to 2016 (Table 2 and Figure 5). The results showed that agricultural land was the main type of land use and occupied proportions of 58.39\% and $27.68 \%$ in 1990 and 2016, respectively. We observe a continuous decrease in agricultural land since the year 1990. Grassland was the second main land cover type in the Yanhe catchment and increases continuously from $31.90 \%$ in 1990 to $43.91 \%$ in 2016 . During the same period, the forest area exhibited an obvious increase from $9.37 \%$ to $26.48 \%$. The forest cover is found in the middle area of the catchment and expanded toward downstream areas. This demonstrated that the Yanhe catchment experienced a fast reforestation program over the last 26 years. The urban land has the least coverage and increased from $0.20 \%$ to $1.80 \%$ during the entire study period. Similarly, the area of water bodies is very small $(0.14 \%)$ and exhibited a slight changes from 1990 to 2016 . The spatial analysis reveals that during 1990-2016, the diminishing area of agricultural land $\left(2343.49 \mathrm{~km}^{2}\right)$ is mainly attributed to the increase in grassland and forest cover in this study catchment. 

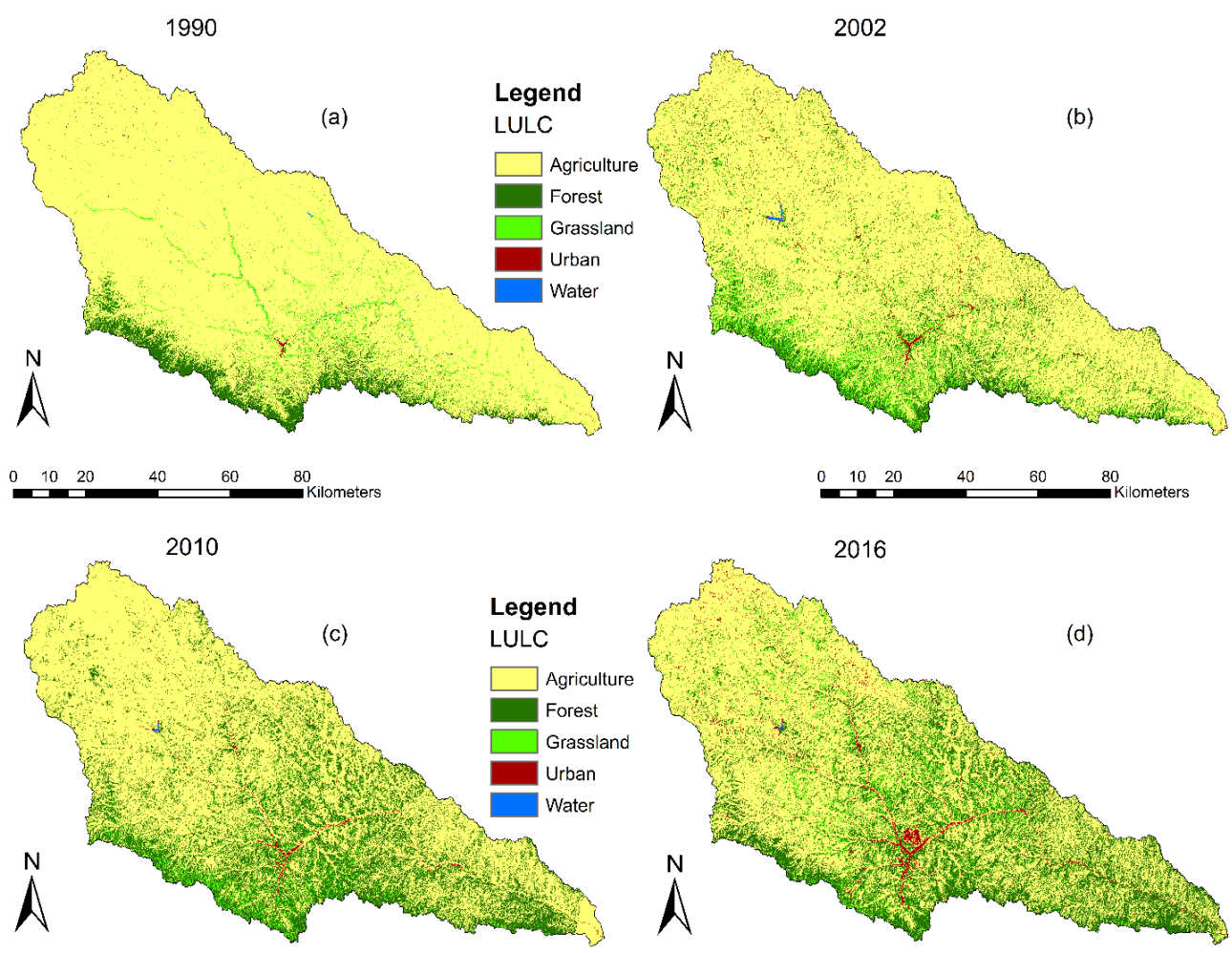

Figure 5. Land use land cover maps of the Yanhe catchment for (a) 1990, (b) 2002, (c) 2010 and (d) 2016.

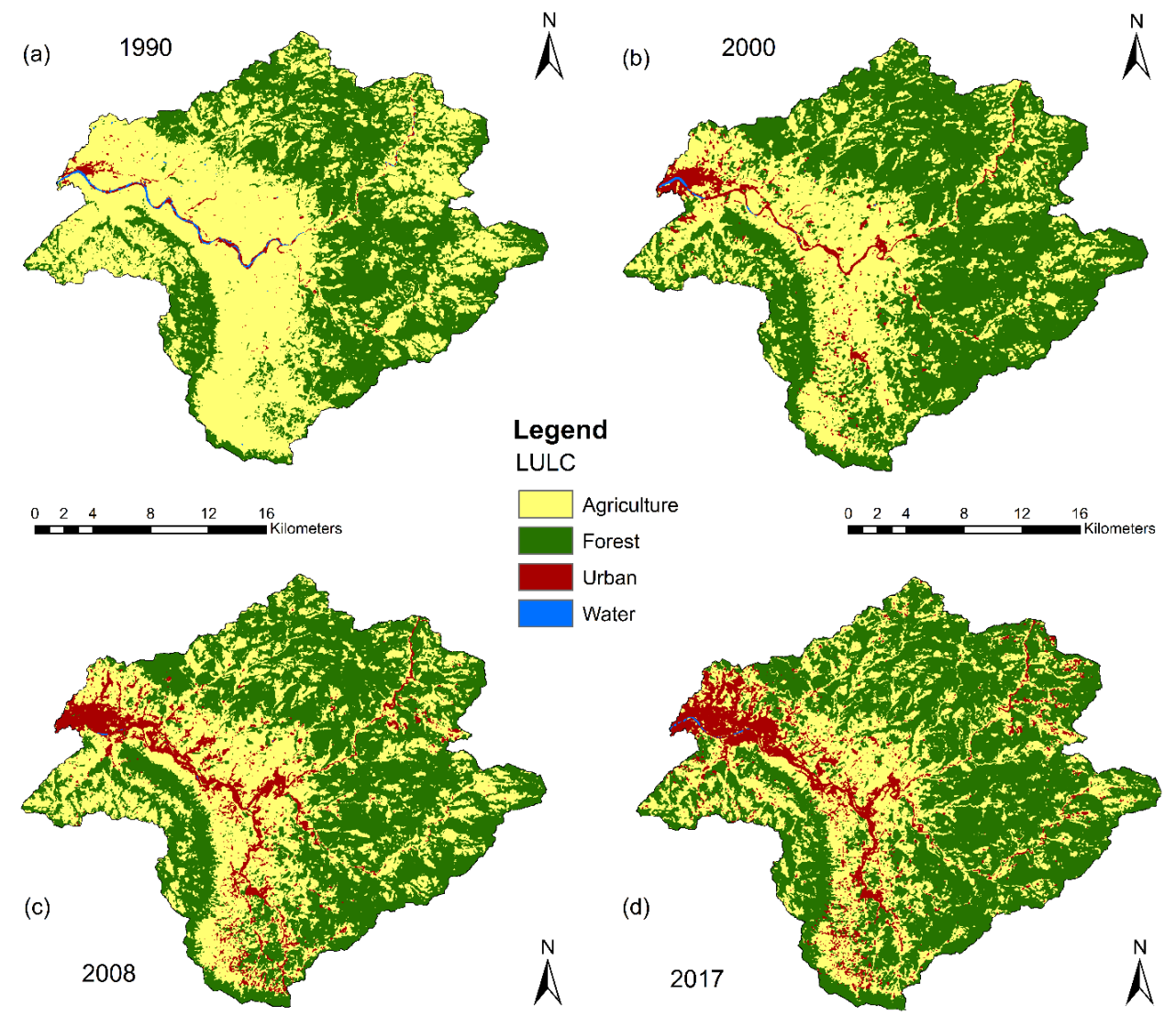

Figure 6. Land use land cover maps of the Guangyuan catchment for (a) 1990, (b) 2000, (c) 2008 and (d) 2017. 
For the Guangyuan catchment, in the year 1990, agricultural land was the most dominant LULC type, occupying $56.55 \%$ of the total area, followed by forest cover type $41.98 \%$, urban area $1.06 \%$ and water bodies $0.41 \%$ (Table 3 and Figure 6). During the whole study period 1990-2017, the agricultural land cover type declined the most from 56.55 to $32.81 \%$ while the other classes such as forest cover and urban area increased. There is a steady increase in forest cover $(16.49 \%)$ in the first period of our analysis (1990-2000) and a slight decrease (-0.8) between 2000 and 2017, probably due to the rapid urbanization (5.61\%) in the later period. In general, from 1990 to 2017, the forest cover exhibited an overall increase of $15.7 \%$. Meanwhile, the urban area expanded eastward of the catchment along the floodplain from 1.06 to $9.16 \%$. The spatial patterns of LULC indicated that mainly agricultural land in the floodplain regions was converted to built-up areas in the surroundings of the 1990 urban center boundary of this study catchment. Further analysis of land cover and slope maps revealed that agricultural land was mainly transformed to forest on steep slopes areas $(>25 \%)$.

Some other studies $[12,36]$ observed the same trend related to the conversion of agricultural land into forest cover and grassland in many mountainous regions of China, including the location of the two studied catchments. The increase in forest coverage is likely attributed to the GTGP and NFCP conservation policies implemented in the late 1990s as a way of reducing soil erosion and floods in many regions in China $[15,70]$.

Table 2. The area percentage of land use land cover from 1990-2016 period in the Yanhe catchment.

\begin{tabular}{ccccccccc}
\hline \multirow{2}{*}{ LULC Type } & \multicolumn{3}{c}{ Land Use Land Cover Area (\%) } & \multicolumn{3}{c}{ Changes in Land Use Land Cover (\%) } \\
\cline { 2 - 9 } & $\mathbf{1 9 9 0}$ & $\mathbf{2 0 0 2}$ & $\mathbf{2 0 1 0}$ & $\mathbf{2 0 1 6}$ & $\mathbf{1 9 9 0 - 2 0 0 2}$ & $\mathbf{2 0 0 0 - 2 0 1 0}$ & $\mathbf{2 0 0 8 - 2 0 1 6}$ & $\mathbf{1 9 9 0 - 2 0 1 6}$ \\
\hline Agriculture & 58.39 & 51.88 & 37.61 & 27.68 & -6.51 & -14.27 & -9.93 & -30.71 \\
Urban & 0.20 & 0.94 & 1.25 & 1.80 & 0.74 & 0.31 & 0.54 & 1.6 \\
Forest & 9.37 & 12.10 & 18.50 & 26.48 & 2.73 & 6.40 & 7.98 & 17.11 \\
Grassland & 31.90 & 34.95 & 42.52 & 43.91 & 3.05 & 7.57 & 1.39 & 12.01 \\
Water & 0.14 & 0.13 & 0.12 & 0.13 & -0.01 & -0.01 & 0.01 & -0.01 \\
Total & 100 & 100 & 100 & 100 & 0 & 0 & 0 & 0 \\
\hline
\end{tabular}

Note: a negative value indicates a decrease in land use land cover (in \%).

Table 3. The area percentage of land use land cover from the 1990-2017 period in the Guangyuan catchment.

\begin{tabular}{ccccccccc}
\hline \multirow{2}{*}{ LULC Type } & \multicolumn{3}{c}{ Land Use Land Cover Area (\%) } & \multicolumn{3}{c}{ Changes in Land Use Land Cover (\%) } \\
\cline { 2 - 9 } & $\mathbf{1 9 9 0}$ & $\mathbf{2 0 0 0}$ & $\mathbf{2 0 0 8}$ & $\mathbf{2 0 1 7}$ & $\mathbf{1 9 9 0 - 2 0 0 0}$ & $\mathbf{2 0 0 0 - 2 0 0 8}$ & $\mathbf{2 0 0 8 - 2 0 1 7}$ & $\mathbf{1 9 9 0 - 2 0 1 7}$ \\
\hline Agriculture & 56.55 & 37.57 & 39.18 & 32.81 & -18.98 & 1.61 & -6.37 & -23.74 \\
Urban & 1.06 & 3.55 & 7.88 & 9.16 & 2.49 & 4.33 & 1.28 & 8.1 \\
Forest & 41.98 & 58.47 & 52.92 & 57.67 & 16.49 & -5.55 & 4.75 & 15.69 \\
Water & 0.41 & 0.40 & 0.02 & 0.36 & -0.01 & -0.38 & 0.34 & -0.05 \\
Total & 100 & 100 & 100 & 100 & 0 & 0 & 0 & 0 \\
\hline
\end{tabular}

Note: a negative value indicates a decrease in land use land cover (in \%).

\subsection{Vegetation Analysis}

The NDVI classification maps show spatiotemporal changes in vegetation cover for the two study catchments (Figures 7 and 8). The analysis of the NDVI classification maps indicates that the vegetation cover area experienced an increasing trend in both catchments. In the Yanhe catchment, from 1990 to 2016, the NDVI increased by 0.14 (from 0.78 to 0.92 ). Spatially, the lowest NDVI values were observed in the upstream areas whereas the increasing trends in NDVI were observed in the midstream towards downstream areas of the catchment (Figure 7). These regions with higher NDVI values have been the most affected by increases in forest and grassland cover. 

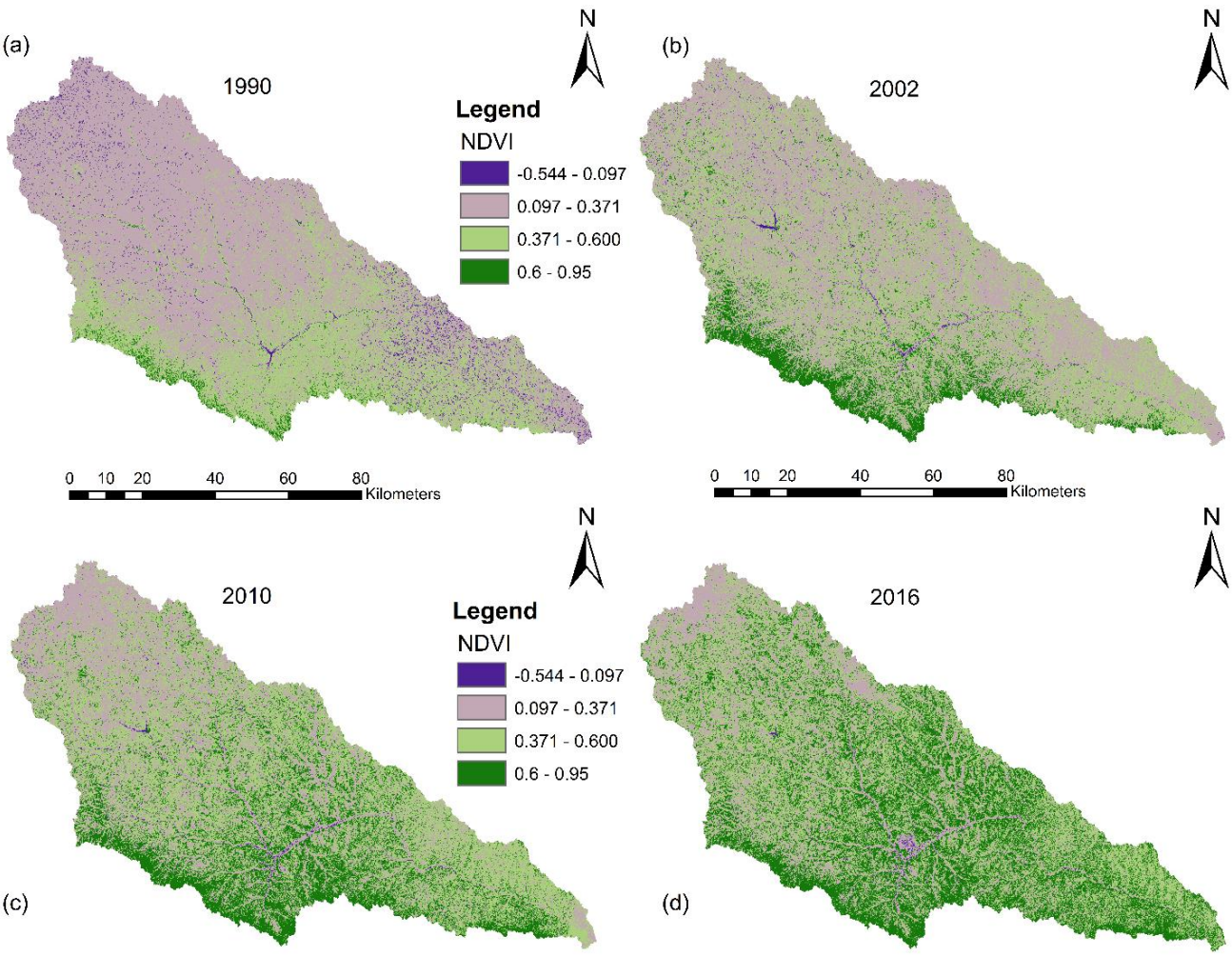

Figure 7. Spatial variations of the NDVI of the Yanhe watershed for 1990 (a), 2002 (b), 2010 (c) and 2016 (d).
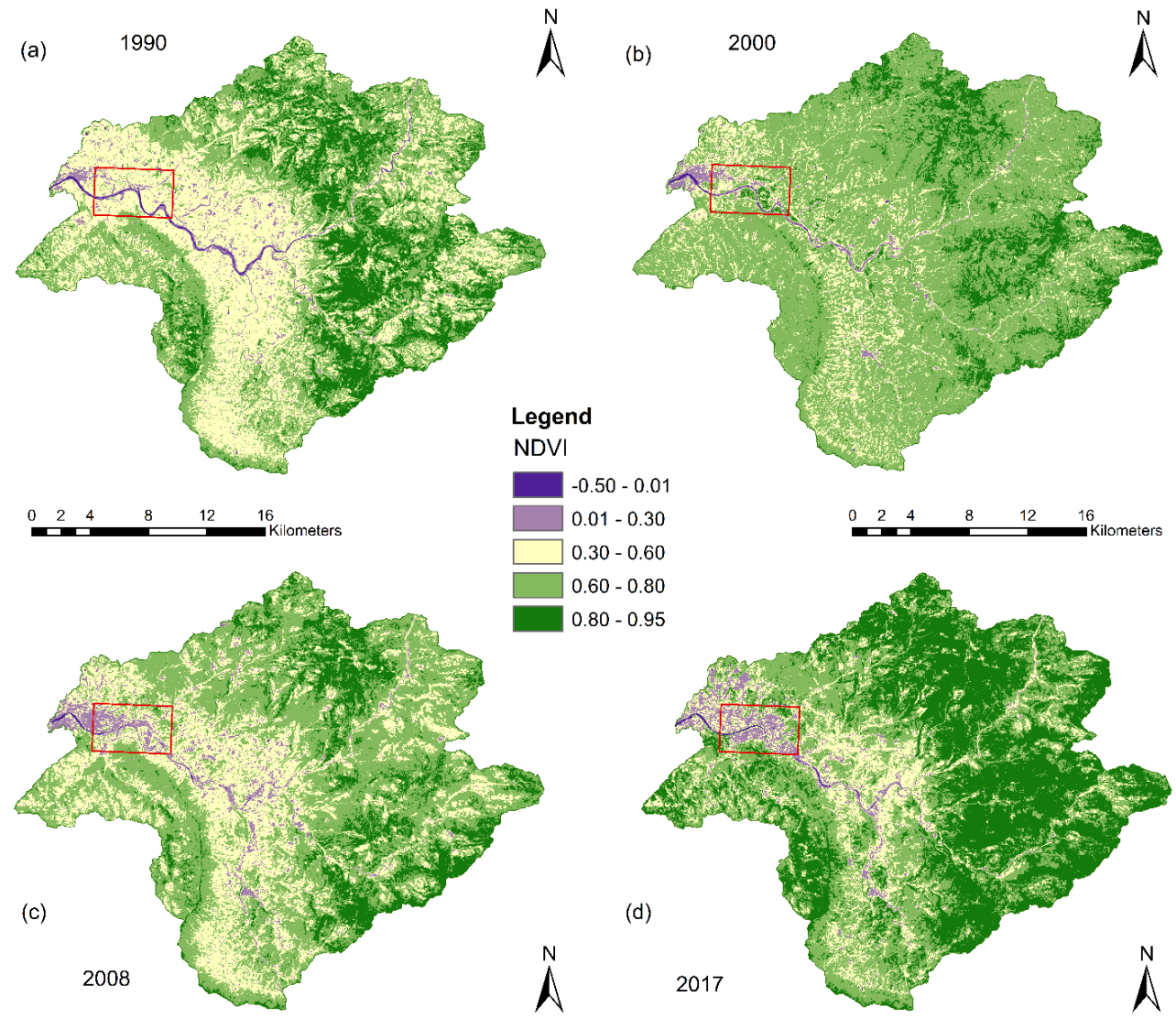

Figure 8. Spatial variations of the NDVI of the Guangyuan watershed for 1990 (a), 2000 (b), 2008 (c) and 2016 (d). 
For the Guangyuan catchment, the mean NDVI value increased from 0.60 in 1990 to 0.85 in 2017. The highest increment in the NDVI value was observed in upstream hilly areas of the study catchment (Figure 8). The spatial analysis of LULC maps shows the increase in forest coverage on steep slopes $(>25 \%)$. On the other hand, we observed a sharp decline in NDVI values in the low elevation areas near the catchment outlet and alongside the river floodplain. The analysis of the LULC maps revealed the highest expansion in urban land (4.33\%) in these regions from 1990 to 2017.

The increasing trend in NDVI indicates that both catchments were affected by various reforestation and afforestation programs (e.g., NFCP and GTGP) introduced since the 1990s. These conservation projects reflect the effort made to restore vegetation cover in various mountainous regions in China, including the two study catchments. Overall, our results are consistent with other research findings [20] conducted in these regions where the increasing trends in NDVI were noted after the implementation of the Grain to Green Program.

\subsection{Impact of Reforestation Driven LULC Changes on Flood Peak Discharge}

The HEC-HMS model was applied in each catchment for four different land cover scenarios (S1, S2, S3 and S4) using the same meteorological input. The simulated flash flood hydrographs at the catchment outlet decreased between the baseline scenario S1 and fourth scenario S4 (Table 4 and Figure 9). The magnitude of changing flood peak discharge was different in each catchment. For the Yanhe catchment, we observed a larger decreasing trend in flash flood peak discharge from 1990 to 2016 (Figure 9a). A maximum decrease in flood peak discharge of 14.35\% between scenario S4 (2016 LULC) and baseline scenario S1 (1990 LULC) was recorded. Similar decreasing trends in peak discharge were noted in scenario S2 (2002 LULC) and scenarios S3 (2010 LULC) as shown in Table 4. These findings show that reforestation induced land cover changes probably led to a continuous decrease in flood peak discharge since the 1990s. From 1990 to 2016, the Yanhe catchment had undergone an expansion in forest and grassland cover and a decrease in agricultural land (see Section 3.1). Additionally, this change in land cover was reflected in changing NDVI values, which increased by 0.14 during the same period. As discussed by other authors [16,71], the vegetation cover intercepts rainfall and increases surface roughness (Manning's coefficients), which result in higher soil infiltration capacity and a decrease in surface runoff and streamflow.

In the Guangyuan catchment, the HEC-HMS simulated results showed that between 1990 to 2017, the flood peak discharge decreases up to $-6.2 \%$ in scenario S4 (2017 LULC) compared to the baseline scenario S1 (1990 LULC) at the catchment outlet (Figure 9b). However, scenario S2 (2000 LULC) was the most effective in reducing flood peak discharge (up to $-7.5 \%$ ). In general, all three scenarios (S2, S3, and S4) showed a decreasing tendency in peak discharge compared to the baseline scenario (S1) as presented in Table 4. Many possible reasons explain the observed unsteady changes in flash flood peak discharge noted from 1990 to 2016. First, for the baseline scenario S1 (LULC1990), the analysis of the land cover map showed that in the year 1990, agricultural land was the main LULC type, occupying more than $56.55 \%$ of the total area of the study catchment. Previous studies [72] argued that the expansion of agricultural land led to the increase in streamflow, which might explain the cause of the highest flood peak discharge observed during the baseline scenario (S1). Second, the conversion of agricultural land to forest and grasslands between 1990 and 2000 had more effect on the larger percentage reduction in flood peak discharge registered in scenario S2 (2000LULC). Third, we observed a high rise in built-up areas (4.3\%) from 2000 to 2008 on the fringe of the 1990 city boundary mainly along the floodplain. This probably increased the surface runoff, which led to little increase in peak discharge in scenario S3 (2008LULC). 
(a)

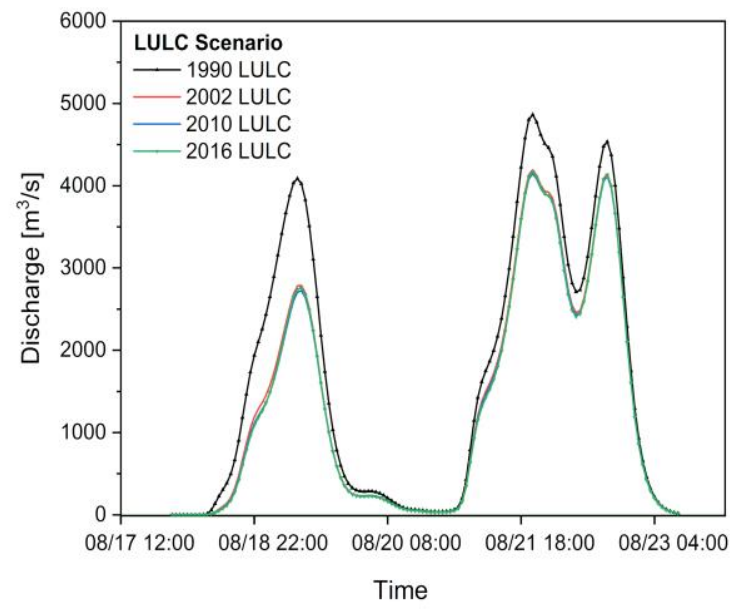

(b)

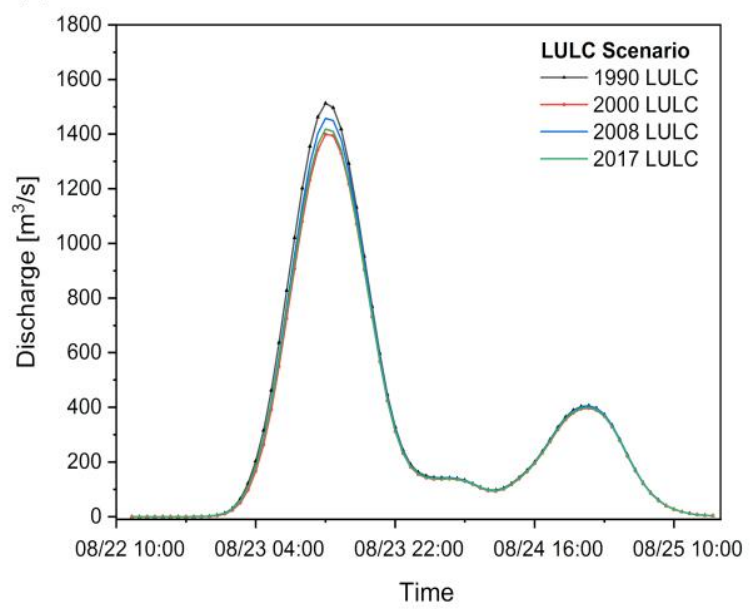

Figure 9. Simulated hydrographs for different land use land cover scenarios at the Yanhe (a) and Guangyuan (b) watersheds.

Overall, our results demonstrated that the changes in land cover driven by afforestation activities (e.g., GTGP and NFCP) across the two mountainous catchments were probably the main cause of decreasing flood peak discharge during the 1990-2016/2017. Moreover, the difference in the catchment area and location of changed land cover might have caused the observed variation in peak discharge at the outlet of each catchment. As discussed by Jansson et al. [22], the location of vegetation cover in the watershed often contributes to the amount of changes in streamflow at the outlet. Our findings agree with other previous studies $[73,74]$ conducted in various watersheds in China, where the increase in woodland resulted in a lower runoff and water discharge. Elsewhere, authors reported the reduction in forest cover driven by human activities as the main cause of increases in surface runoff and flood peak discharge [75-77].

Table 4. Modeling comparison of different LULC changes scenarios for the Yanhe and Guangyuan watersheds.

\begin{tabular}{|c|c|c|c|c|c|}
\hline \multicolumn{3}{|c|}{ Yanhe Catchment } & \multicolumn{3}{|c|}{ Guangyuan Catchment } \\
\hline $\begin{array}{l}\text { LULC Changes } \\
\text { Scenario }\end{array}$ & $\begin{array}{c}\text { Flood Peak } \\
\text { Discharge }\left(\mathrm{m}^{3} / \mathrm{s}\right) \\
\text { per Scenario }\end{array}$ & $\begin{array}{c}\text { Relative } \\
\text { Change (\%) }\end{array}$ & $\begin{array}{l}\text { LULC Changes } \\
\text { Scenario }\end{array}$ & $\begin{array}{c}\text { Flood Peak } \\
\text { Discharge } \\
\left(\mathrm{m}^{3} / \mathrm{s}\right) \text { per } \\
\text { Scenario }\end{array}$ & $\begin{array}{c}\text { Relative } \\
\text { Change (\%) }\end{array}$ \\
\hline $\begin{array}{l}\text { Scenario S1 } \\
\text { (1990LULC) }\end{array}$ & 4865.8 & - & $\begin{array}{l}\text { Scenario S1 } \\
\text { (1990LULC) }\end{array}$ & 1512.7 & - \\
\hline $\begin{array}{l}\text { Scenario S2 } \\
\text { (2002LULC) }\end{array}$ & 4195.3 & -13.7 & $\begin{array}{l}\text { Scenario S2 } \\
\text { (2000LULC) }\end{array}$ & 1399.7 & -7.4 \\
\hline $\begin{array}{l}\text { Scenario S3 } \\
\text { (2008LULC) }\end{array}$ & 4144.9 & -14 & $\begin{array}{l}\text { Scenario S3 } \\
\text { (2010LULC) }\end{array}$ & 1458.5 & -3.5 \\
\hline $\begin{array}{l}\text { Scenario S4 } \\
\text { (2016LULC) }\end{array}$ & 4167.4 & -14.3 & $\begin{array}{l}\text { Scenario S4 } \\
\text { (2017LULC) }\end{array}$ & 1418.3 & -6.2 \\
\hline
\end{tabular}

Note: a negative value of relative changes indicates a decrease.

\subsection{Spatial Variability of Flood Peak Discharge at the Sub-Basin Scale}

The spatial distributions of changes in peak discharge at the sub-basin scale in the Yanhe and Guangyuan catchments between S1 and S4 are shown in Figures 10 and 11, respectively. These figures show that the extent of peak discharge decrease differed among sub-basins. For the Yanhe catchment, from 1990 to 2016, the highest decreases in peak discharge were observed in the midstream and downstream sub-basins with a maximum percentage change of approximately 17.7\% (Figure 10). 
The spatial analysis of land cover changes showed that these sub-basins were associated with the replacement of agricultural land by forest and grassland cover. Moreover, these sub-basins had higher NDVI, with a maximum value of 0.95 in 2016, which confirms the presence of higher vegetation coverage. On the other hand, the lowest decrease in peak discharge, were noted in the northern portion of sub-basins with a minimum percentage change of $7 \%$. The spatial distribution pattern of land cover type shows that these sub-basins largely match with agriculture activities and experienced a little increase in grassland and forest coverage during our study period. Furthermore, we selected individual sub-basins with significant changes in various land cover type and assess their hydrological response during 1990-2016. For example, the expansion of urban land in sub-basin W850 resulted in a slight decrease in peak discharge (4.9\%). In contrast, the increase in forest and grassland in sub-basin W960, resulted in the highest decrease in peak discharge up to $14 \%$ during the same study period (Figure 12a). Overall, all sub-basins showed a decreasing trend at various degrees in peak discharge from 1990 to 2016 in this study catchment. The observed variation in peak discharge among sub-basins might have been caused by the higher rate conversion of agricultural land to forest and grassland cover between the year 1990 and 2017 in these sub-basins.

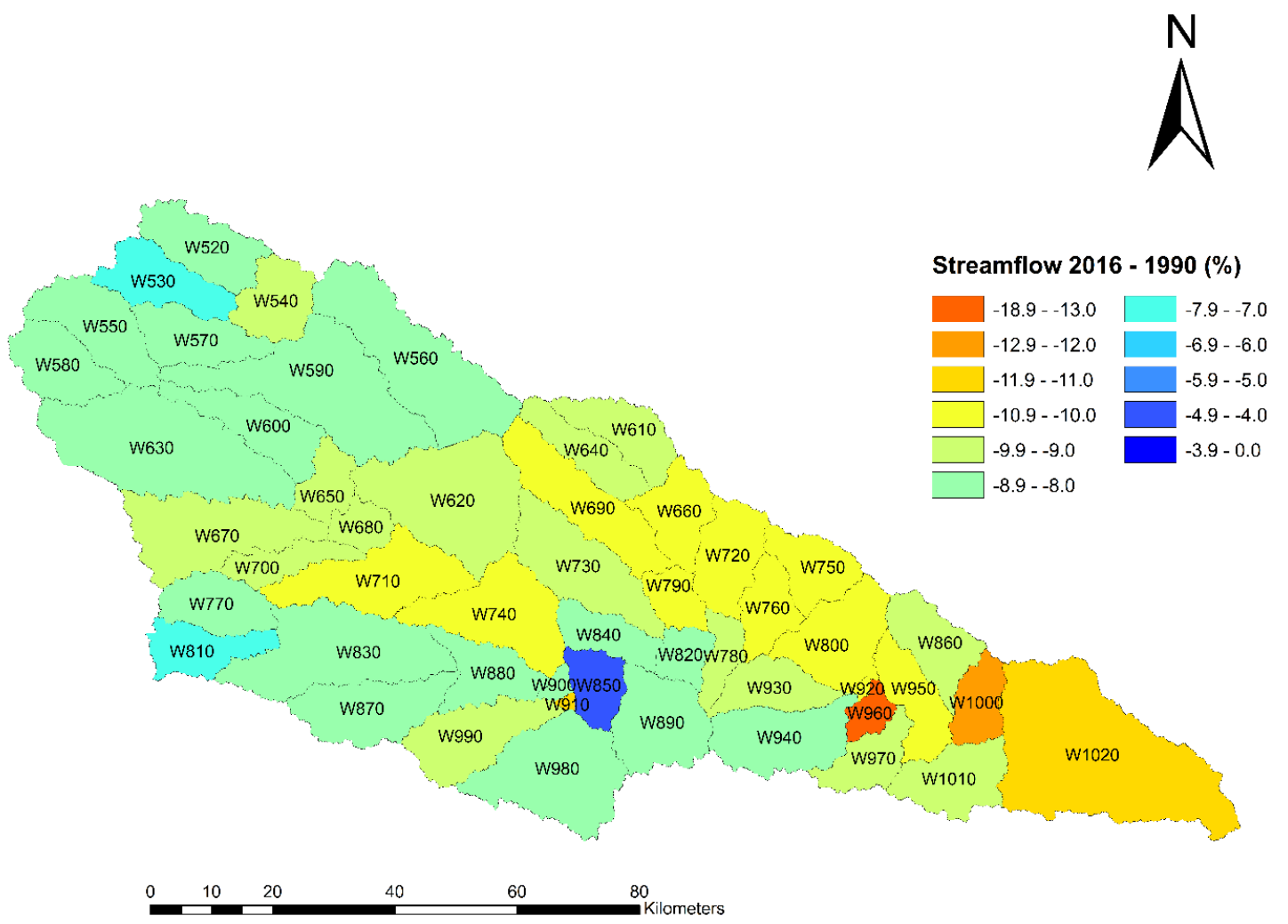

Figure 10. Spatial variations of changes in peak discharge (\%) at the sub-basin scale for the simulation period 1990-2016 in the Yanhe watershed (Note: a negative value indicates a decrease in streamflow).

In the Guangyuan catchment, the highest decrease in peak discharge (up -19.06\%) occurred in the upstream (southern and eastern) sub-basins during 1990-2017 (Figure 11). Conversely, the downstream sub-basins showed an increasing tendency in peak discharge (up to $39.27 \%$ ). The spatial patterns of land cover and the analysis of NDVI maps indicate a significant increase in urban land in downstream sub-basins and an expansion of forest cover in upstream sub-basins. Therefore, the urbanized sub-basins were probably the main source of surface runoff that increased the peak discharge in downstream areas while the forest coverage reduced the peak discharge in upper areas. Moreover, the analysis of some individual sub-basins provided further understanding on the effect of sub-basins land cover change on hydrological responses. For example, from 1990 to 2017 in the urbanized 
sub-basin W900, the streamflow changed from 73.60 to $102.5 \mathrm{~m}^{3} / \mathrm{s}$. On the contrary, in the forested sub-basin W1180, the streamflow decreased from 77.4 to $64.8 \mathrm{~m}^{3} / \mathrm{s}$ during the same period (Figure 12b). These findings indicate that the changes in land cover driven by GTGP and NFCP certainly affected more the sub-basins hydrological response behavior than the whole catchment.

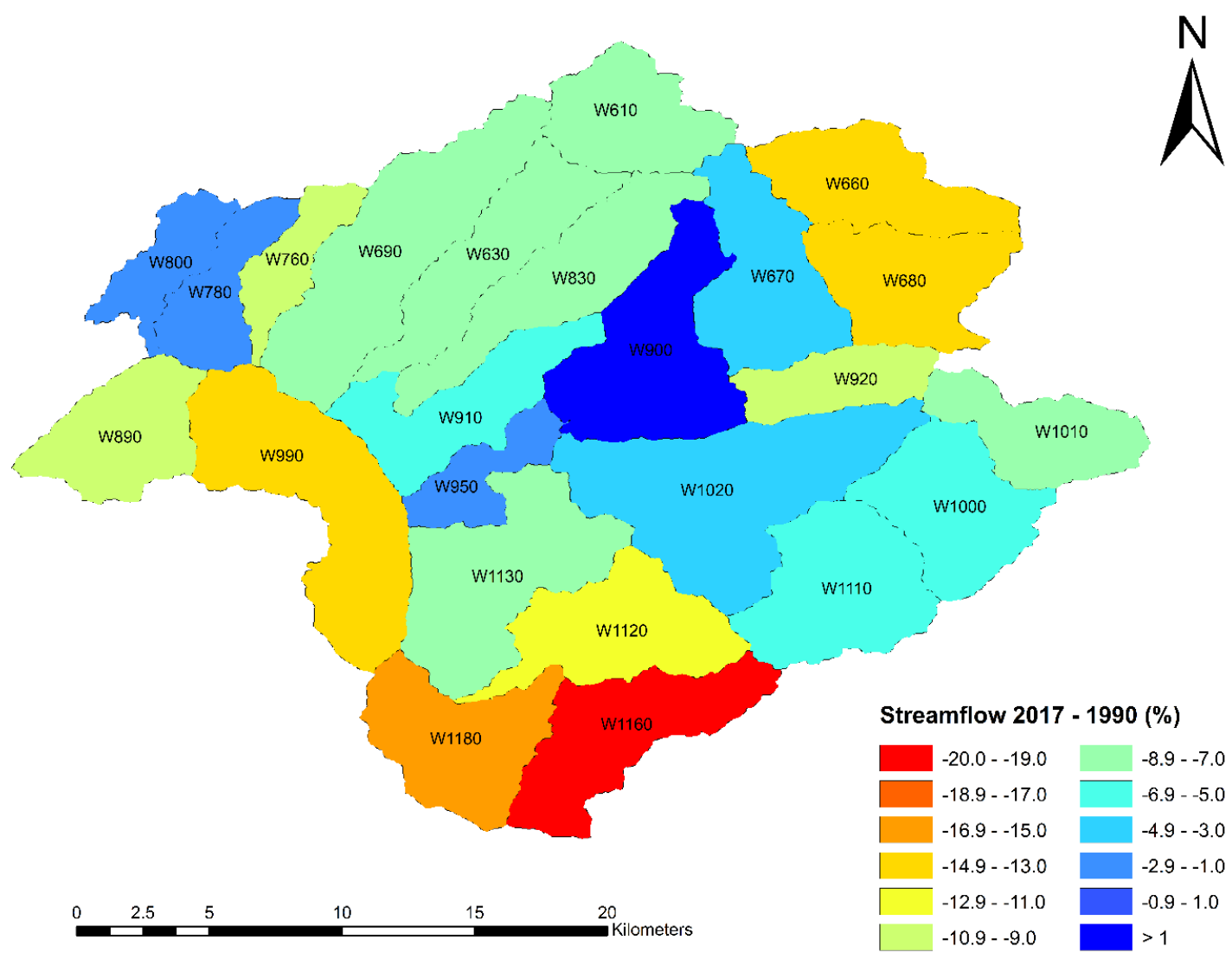

Figure 11. Spatial variations of changes in peak discharge (\%) at the sub-basin scale for the simulation period 1990-2017 for the Guangyuan watershed (Note: a negative value indicates a decrease in streamflow).

The analysis of hydrological behavior at the sub-basin scale in both catchments was consistent with the magnitude of change of NDVI values (see Section 3.2). We observed no significant correlation ( $p>0.10$ for both catchments) between changes in NDVI and flood peak discharge at the sub-basin scale. For example, the increase in NDVI by $19 \%$ led to a decrease in peak discharge by $8 \%$ in one sub-basin of the Guangyuan catchment. In general, sub-basins that showed higher decreasing trends in flood peak discharge were characterized by larger increases in NDVI values than sub-basins that exhibited low or non-decrease in peak discharge. Moreover, the sensitivity analysis exposed a positive correlation $\left(\mathrm{r}^{2}=0.99\right)$ between changes in land cover (increase/decrease in $\mathrm{CN}$ ) and simulated peak discharge. For example, the increase in $\mathrm{CN}$ value by $5 \%$ in one sub-basin of the Yanhe catchment has resulted in an increase in peak discharge by $4 \%$. These results indicate that the risk of flash floods in the catchment increases with changing land cover types towards a more urbanized environment. Furthermore, these analyses helped us to better understand the impact of land cover dynamics on catchment hydrological response. Our findings are in line with the study by Liu and Shi [11] who attributed the increase in surface runoff in various urban areas in China to the conversion of floodplains into constructed lands. Moreover, other numerous studies [78,79] discussed the benefit of increases in forest cover in the small catchment and concluded that an increase in vegetation coverage results in a reduction in streamflow. 
(a)

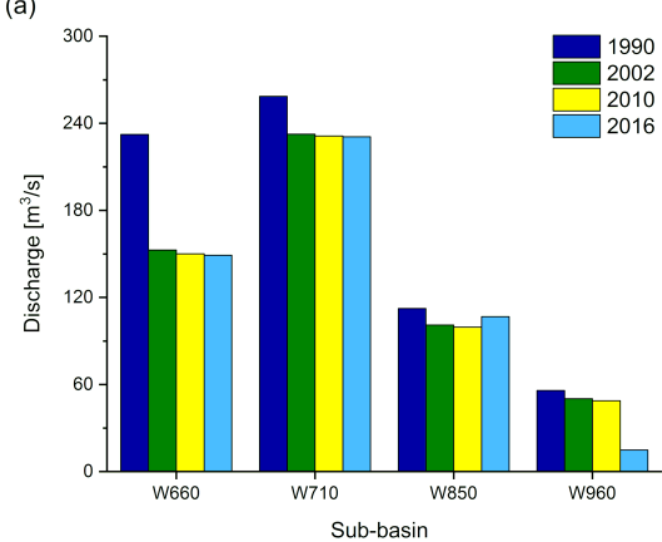

(b)

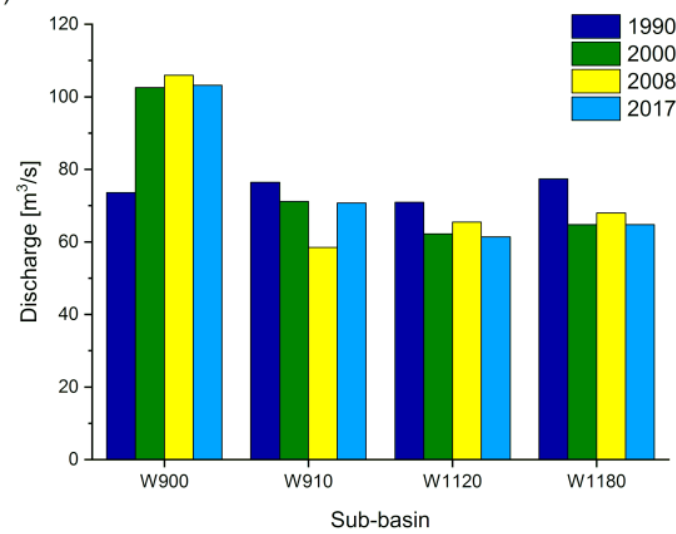

Figure 12. Calculated flood peak discharge $\left(\mathrm{m}^{3} / \mathrm{s}\right)$ of selected sub-basins under different land use land cover scenarios for the Yanhe (a) and Guangyuan (b) watersheds.

\subsection{Limitations}

This study was conducted in mountainous catchments with limited ground discharge data, and due to their inaccessible locations, detailed field surveys for estimation of hydrological parameters were not conducted. Additionally, we used freely available data with medium spatial resolution (e.g., soil data). This may have introduced some uncertainties in the modeling. Nevertheless, by following standard guidance on model input data preparation and processing, these errors have been minimized. Hence, our study provides a reference for better understanding the importance of two main conservation policies introduced in some regions of China to mitigate flash flood and how such program could be useful in other regions. The present study did not consider the impact of climate change due to insufficient long historical climate data, thus, care should be taken while interpreting our results. Some other studies $[4,80-82]$ also reported reliable results while using un-calibrated models.

\section{Summary and Conclusions}

The present study investigated the effect of GTGP and NFCP induced land cover change on flood peak discharge in two mountainous catchments in China since the 1990s. Our results indicate the increase in forest coverage by about $18 \%$ in Yanhe and $16 \%$ in Guangyuan at the expense of agricultural land, reflected in changes in NDVI value and LULC. Similarly, we observed the increase in urban land in some sub-basins in both catchments. These changes in LULC resulted in different hydrological responses in the two catchments. The HEC-HMS simulation results under four different LULC change scenarios showed a decreasing trend in flash flood peak discharge by $\sim 14 \%$ in Yanhe and $\sim 6 \%$ in Guangyuan during the whole study period (1990-2016/2017). Further to this, the spatial analysis of catchment hydrological response to land cover changes at the sub-basin scale was much more significant. The forested sub-basins demonstrated a high decreasing rate in peak discharge ranging from $17 \%$ in Yanhe to 19\% in Guangyuan while few urbanized sub-basins showed an increasing trend in peak discharge up to 39\%. It appears that the expansion of forest and grassland caused by the GTGP and NFCP policies certainly had great potential in reducing the flood peak discharge in the two studied catchments. Despite providing reference for better understanding the importance of implementing sustainable land cover policies (e.g., reforestation) in mountainous regions, these findings provide useful information for decision makers to establish proper flood control measures. Considering that, the present study only explored the influence of conservation programs (e.g., GTGP) on mountainous catchment hydrological responses, future research shall explore the effect of other factors such as climate conditions and socioeconomic variables. 
Author Contributions: Conceptualization, R.L. and C.K.; Methodology, C.K.; Software, Y.Z.; Validation, Y.W.; Formal Analysis, M.M.; Investigation, J.G.; Resources, R.L. and J.G.; Data Curation, Z.G.; Writing-Original Draft Preparation, C.K. and R.L.; Visualization, D.E.R.R.; Supervision, R.L.; Project Administration, R.L.; Funding Acquisition, R.L. All authors have read and agreed to the published version of the manuscript.

Funding: This work was supported by the National Natural Science Foundation of China NSFC (Grant No. 41661144007, 41830104, 41675022, 41375148), the National Key Research and Development Program of China (Grant No.2017YFC1501402), and the Jiangsu Provincial 2011 Program (Collaborative Innovation Center of Climate Change).

Acknowledgments: The first author has a doctoral grant funded by the Chinese Academy of Science (CAS) and The World Academy of Sciences (TWAS). We thank the United States Geological Survey (USGS) for open access to the Landsat imagery archive. We would also like to thank the four anonymous reviewers for their constructive comments which helped us to improve the quality of this research work.

Conflicts of Interest: We have no conflicts of interest to disclose.

\section{References}

1. Diakakis, M.; Priskos, G.; Skordoulis, M. Public perception of flood risk in flash flood prone areas of Eastern Mediterranean: The case of Attica Region in Greece. Int. J. Disaster Risk Reduct. 2018, 28, 404-413. [CrossRef]

2. Hrachowitz, M.; Savenije, H.H.G.; Blöschl, G.; McDonnell, J.J.; Sivapalan, M.; Pomeroy, J.W.; Arheimer, B.; Blume, T.; Clark, M.P.; Ehret, U.; et al. A decade of Predictions in Ungauged Basins (PUB)—A review. Hydrol. Sci. J. 2013, 58, 1198-1255. [CrossRef]

3. Kourgialas, N.N.; Karatzas, G.P. A national scale flood hazard mapping methodology: The case of Greece-Protection and adaptation policy approaches. Sci. Total. Environ. 2017, 601, 441-452. [CrossRef] [PubMed]

4. Rozalis, S.; Morin, E.; Yair, Y.; Price, C. Flash flood prediction using an uncalibrated hydrological model and radar rainfall data in a Mediterranean watershed under changing hydrological conditions. J. Hydrol. 2010, 394, 245-255. [CrossRef]

5. Modrick, T.M.; Georgakakos, K.P. The character and causes of flash flood occurrence changes in mountainous small basins of Southern California under projected climatic change. J. Hydrol. Reg. Stud. 2015, 3, 312-336. [CrossRef]

6. Skougaard Kaspersen, P.; Høegh Ravn, N.; Arnbjerg-Nielsen, K.; Madsen, H.; Drews, M. Comparison of the impacts of urban development and climate change on exposing European cities to pluvial flooding. Hydrol. Earth Syst. Sci. 2017, 21, 4131-4147. [CrossRef]

7. Douinot, A.; Roux, H.; Garambois, P.A.; Larnier, K.; Labat, D.; Dartus, D. Accounting for rainfall systematic spatial variability in flash flood forecasting. J. Hydrol. 2016, 541, 359-370. [CrossRef]

8. Li, W.; Lin, K.; Zhao, T.; Lan, T.; Chen, X.; Du, H.; Chen, H. Risk assessment and sensitivity analysis of flash floods in ungauged basins using coupled hydrologic and hydrodynamic models. J. Hydrol. 2019, 572, 108-120. [CrossRef]

9. Rodriguez-Morata, C.; Ballesteros-cánovas, J.A.; Trappmann, D.; Beniston, M.; Stoffel, M. Regional reconstruction of flash flood history in the Guadarrama range (Central System, Spain). Sci. Total. Environ. 2016, 550, 406-417. [CrossRef]

10. Zhang, Y.; Peng, C.; Li, W.; Tian, L.; Zhu, Q.; Chen, H.; Fang, X.; Zhang, G.; Liu, G.; Mu, X.; et al. Multiple afforestation programs accelerate the greenness in the 'Three North' region of China from 1982 to 2013. Ecol. Indic. 2015, 61, 404-412. [CrossRef]

11. Liu, J.; Shi, Z.-W. Quantifying land-use change impacts on the dynamic evolution of flood vulnerability. Land Use Policy 2017, 65, 198-210. [CrossRef]

12. Wang, X.; Zhou, M.; Li, T.; Ke, Y.; Zhu, B. Land use change effects on ecosystem carbon budget in the Sichuan Basin of Southwest China: Conversion of cropland to forest ecosystem. Sci. Total. Environ. 2017, 609, 556-562. [CrossRef] [PubMed]

13. Jiang, Y.; Zevenbergen, C.; Ma, Y. Urban pluvial flooding and stormwater management: A contemporary review of China's challenges and "sponge cities" strategy. Environ. Sci. Policy 2018, 80, 132-143. [CrossRef]

14. Miao, Q.; Yang, D.; Yang, H.; Li, Z. Establishing a rainfall threshold for flash flood warnings in China's mountainous areas based on a distributed hydrological model. J. Hydrol. 2016, 541, 371-386. [CrossRef] 
15. Liu, J.; Li, S.; Ouyang, Z.; Tam, C.; Chen, X. Ecological and socioeconomic effects of China 's policies for ecosystem services. Proc. Natl. Acad. Sci. USA 2007. [CrossRef]

16. Yang, L.; Wei, W.; Chen, L.; Mo, B. Response of deep soil moisture to land use and afforestation in the semi-arid Loess Plateau, China. J. Hydrol. 2012, 475, 111-122. [CrossRef]

17. Sun, D.; Zhang, D.; Cheng, X. Framework of national non-structural measures for flash flood disaster prevention in China. Water 2012, 4, 272-282. [CrossRef]

18. Posthumus, H.; Hewett, C.J.M.; Morris, J.; Quinn, P.F. Agricultural land use and flood risk management: Engaging with stakeholders in North Yorkshire. Agric. Water Manag. 2008, 95, 787-798. [CrossRef]

19. Li, J.; Wang, Z.; Lai, C.; Wu, X.; Zeng, Z.; Chen, X.; Lian, Y. Response of net primary production to land use and land cover change in mainland China since the late 1980s. Sci. Total. Environ. 2018, 639, 237-247.

20. Sun, W.; Song, X.; Mu, X.; Gao, P.; Wang, F.; Zhao, G. Spatiotemporal vegetation cover variations associated with climate change and ecological restoration in the Loess Plateau. Agric. For. Meteorol. 2015, 209, 87-99. [CrossRef]

21. Ghaffari, G.; Keesstra, S.; Ghodousi, J.; Ahmadi, H. SWAT-simulated hydrological impact of land-use change in the Zanjanrood Basin, Northwest Iran. Hydrol. Process. 2010, 24, 892-903. [CrossRef]

22. Jansson, P.-E.; Kalantari, Z.; Folkeson, L.; Sassner, M.; Lyon, S.W.; Stolte, J.; French, H.K. Quantifying the hydrological impact of simulated changes in land use on peak discharge in a small catchment. Sci. Total Environ. 2013, 466-467, 741-754. [CrossRef]

23. Liu, J.; Shi, Z.; Wang, D. Measuring and mapping the flood vulnerability based on land-use patterns: A case study of Beijing, China. Nat. Hazards 2016, 83, 1545-1565. [CrossRef]

24. Juckem, P.F.; Hunt, R.J.; Anderson, M.P.; Robertson, D.M. Effects of climate and land management change on streamflow in the driftless area of Wisconsin. J. Hydrol. 2008, 355, 123-130. [CrossRef]

25. Zhang, Y.; Guan, D.; Jin, C.; Wang, A.; Wu, J.; Yuan, F. Impacts of climate change and land use change on runoff of forest catchment in northeast China. Hydrol. Process. 2014, 28, 186-196. [CrossRef]

26. Liu, M.; Tian, H.; Yang, Q.; Yang, J.; Song, X.; Lohrenz, S.E.; Cai, W.J. Long-term trends in evapotranspiration and runoff over the drainage basins of the Gulf of Mexico during 1901-2008. Water Resour. Res. 2013, 49, 1988-2012. [CrossRef]

27. Chu, H.J.; Lin, Y.P.; Huang, C.W.; Hsu, C.Y.; Chen, H.Y. Modelling the hydrologic effects of dynamic land-use change using a distributed hydrologic model and a spatial land-use allocation model. Hydrol. Process. 2010, 24, 2538-2554. [CrossRef]

28. Alkama, R.; Marchand, L.; Ribes, A.; Decharme, B. Detection of global runoff changes: Results from observations and CMIP5 experiments. Hydrol. Earth Syst. Sci. 2013, 17, 2967-2979. [CrossRef]

29. Wilk, J.; Andersson, L.; Plermkamon, V. Hydrological impacts of forest conversion to agriculture in a large river basin in Northeast Thailand. Hydrol. Process. 2001, 15, 2729-2748. [CrossRef]

30. Cavalcante, R.B.L.; Pontes, P.R.M.; Souza-Filho, P.W.M.; Souza, E.B. Opposite Effects of Climate and Land Use Changes on the Annual Water Balance in the Amazon Arc of Deforestation. Water Resour. Res. 2019, 55, 3092-3106. [CrossRef]

31. Lian, J.; Yang, W.; Xu, K.; Ma, C. Flash flood vulnerability assessment for small catchments with a material flow approach. Nat. Hazards 2017, 88, 699-719. [CrossRef]

32. Zhang, D.-W.; Quan, J.; Zhang, H.-B.; Wang, F.; Wang, H.; He, X.-Y. Flash flood hazard mapping: A pilot case study in Xiapu River Basin, China. Water Sci. Eng. 2015, 8, 195-204. [CrossRef]

33. Yang, X.; Sun, W.; Li, P.; Mu, X.; Gao, P.; Zhao, G. Reduced sediment transport in the Chinese Loess Plateau due to climate change and human activities. Sci. Total. Environ. 2018, 642, 591-600. [CrossRef] [PubMed]

34. Zhao, G.; Mu, X.; Jiao, J.; An, Z.; Klik, A.; Wang, F.; Jiao, F.; Yue, X.; Gao, P.; Sun, W. Evidence and Causes of Spatiotemporal Changes in Runoff and Sediment Yield on the Chinese Loess Plateau. J. Land Degrad. Dev. 2017, 9, 1-11. [CrossRef]

35. Zhang, J.; Wang, T.; Ge, J. Assessing vegetation cover dynamics induced by policy-driven ecological restoration and implication to soil erosion in southern China. PLoS ONE 2015, 10, e0131352. [CrossRef]

36. Xie, X.; Liang, S.; Yao, Y.; Jia, K.; Meng, S.; Li, J. Detection and attribution of changes in hydrological cycle over the Three-North region of China: Climate change versus afforestation effect. Agric. For. Meteorol. 2015, 203, 74-87. [CrossRef]

37. Liu, Y.; Yuan, X.; Guo, L.; Huang, Y.; Zhang, X. Driving Force Analysis of the Temporal and Spatial Distribution of Flash Floods in Sichuan Province. Sustainability 2017, 9, 1527. [CrossRef] 
38. FAO; IIASA; ISRIC; ISSCAS; JRC. Harmonized World Soil Database, version 1.2; FAO: Rome, Italy; IIASA: Laxenburg, Austria, 2012.

39. John, E.W.; Groen, T.A.; Eric, S.; Victor, J. Monitoring basin-scale land cover changes in Kagera Basin of Lake Victoria using ancillary data and remote sensing. Int. J. Appl. Earth Obs. Geoinf. 2013, 21, 32-42. [CrossRef]

40. Liu, X.; Hu, G.; Chen, Y.; Li, X.; Xu, X.; Li, S.; Pei, F.; Wang, S. High-resolution multi-temporal mapping of global urban land using Landsat images based on the Google Earth Engine Platform. Remote. Sens. Environ. 2018, 209, 227-239. [CrossRef]

41. Estoque, R.C.; Pontius, R.G.; Murayama, Y.; Hou, H.; Thapa, R.B.; Lasco, R.D.; Villar, M.A. Simultaneous comparison and assessment of eight remotely sensed maps of Philippine forests. Int. J. Appl. Earth Obs. Geoinf. 2018, 67, 123-134. [CrossRef]

42. Jacobson, A.; Dhanota, J.; Godfrey, J.; Jacobson, H.; Rossman, Z.; Stanish, A.; Walker, H.; Riggio, J. A novel approach to mapping land conversion using Google Earth with an application to East Africa. Environ. Model. Softw. 2015, 72, 1-9. [CrossRef]

43. Prasad, S.T.; Mitchell, S.H.T. Ganges and Indus river basin land use/land cover (LULC) and irrigated area mapping using continuous streams of MODIS data. Remote. Sens. Environ. 2005, 95, 317-341. [CrossRef]

44. Kun, J.; Wu, B.; Tian, Y.; Zeng, Y.; Li, Q. Vegetation classification method with biochemical composition estimated from remote sensing data. Int. J. Remote. Sens. 2011, 1161. [CrossRef]

45. Anderson, J.R. A Land Use and Land Cover Classification System for Use with Remote Sensor Data; US Government Printing Office: Washington, DC, USA, 1976; Volume 964.

46. Zhang, Z.; Wang, X.; Zhao, X.; Liu, B.; Yi, L.; Zuo, L.; Wen, Q.; Liu, F.; Xu, J.; Hu, S. A 2010 update of National Land Use/Cover Database of China at $1: 100000$ scale using medium spatial resolution satellite images. Remote. Sens. Environ. 2014, 149, 142-154. [CrossRef]

47. Deb, S.; Ahmed, A.; Datta, D. An alternative approach for delineating eco-sensitive zones around a wildlife sanctuary applying geospatial techniques. Environ. Monit. Assess. 2014, 2641-2651. [CrossRef] [PubMed]

48. Gashaw, T.; Tulu, T.; Argaw, M.; Worqlul, A.W. Modeling the hydrological impacts of land use/land cover changes in the Andassa watershed, Blue Nile Basin, Ethiopia. Sci. Total. Environ. 2007, 620, 1394-1408. [CrossRef]

49. Lu, D.; Mausel, P.; Brondízio, E.; Moran, E. Change detection techniques. Int. J. Remote. Sens. 2004, 1161. [CrossRef]

50. Bayarsaikhan, U.; Boldgiv, B.; Kim, K.-R.; Park, K.-A.; Lee, D. Change detection and classification of land cover at Hustai National Park in Mongolia. Int. J. Appl. Earth Obs. Geoinf. 2009, 11, 273-280. [CrossRef]

51. Napoli, M.; Massetti, L.; Orlandini, S. Hydrological response to land use and climate changes in a rural hilly basin in Italy. Catena 2017, 157, 1-11. [CrossRef]

52. Hutchinson, J.M.S.; Jacquin, A.; Hutchinson, S.L.; Verbesselt, J. Monitoring vegetation change and dynamics on U.S. Army training lands using satellite image time series analysis. J. Environ. Manag. 2015, 150, 355-366. [CrossRef]

53. Li, S.; Liang, W.; Fu, B.; Lü, Y.; Fu, S.; Wang, S.; Su, H. Vegetation changes in recent large-scale ecological restoration projects and subsequent impact on water resources in China's Loess Plateau. Sci. Total. Environ. 2016, 569, 1032-1039. [CrossRef]

54. Liu, N.; Harper, R.J.; Smettem, K.R.J.; Dell, B.; Liu, S. Responses of streamflow to vegetation and climate change in southwestern Australia. J. Hydrol. 2019, 572, 761-770. [CrossRef]

55. Wei, X.; Li, Q.; Zhang, M.; Giles-Hansen, K.; Liu, W.; Fan, H.; Wang, Y.; Zhou, G.; Piao, S.; Liu, S. Vegetation cover-another dominant factor in determining global water resources in forested regions. Glob. Chang. Biol. 2018, 24, 786-795. [CrossRef] [PubMed]

56. Robinson, N.P.; Allred, B.W.; Jones, M.O.; Moreno, A.; Kimball, J.S.; Naugle, D.E.; Erickson, T.A.; Richardson, A.D. A Dynamic Landsat Derived Normalized Difference Vegetation Index (NDVI) Product for the Conterminous United States. Remote. Sens. 2017, 9, 863. [CrossRef]

57. USACE. Hydrologic Modeling System HEC-HMS Technical Reference Manual; Institute for Water Resources, Hydrologic Engineering Center (HEC): Davis, CA, USA, 2013.

58. USACE. Hydrologic Modeling System HEC-HMS Technical Reference Manual; Institute for Water Resources, Hydrologic Engineering Center (HEC): Davis, CA, USA, 2000. 
59. Sanyal, J.; Densmore, A.L.; Carbonneau, P. Analysing the effect of land-use cover changes at sub-catchment levels on downstream flood peaks: A semi-distributed modelling approach with sparse data. Catena 2014, 118, 28-40. [CrossRef]

60. Marchi, L.; Borga, M.; Preciso, E.; Gaume, E. Characterisation of selected extreme flash floods in Europe and implications for flood risk management. J. Hydrol. 2010, 394, 118-133. [CrossRef]

61. Haberlandt, U. Geostatistical interpolation of hourly precipitation from rain gauges and radar for a large-scale extreme rainfall event. J. Hydrol. 2007, 144-157. [CrossRef]

62. U.S.S.C. SCS National Engineering Handbook, Section 4, Hydrology; Reproduced by National Technical Information Service; U.S. Dept. of Agriculture, Soil Conservation Service: Washington, DC, USA, 1972.

63. El-Hames, A.S. An empirical method for peak discharge prediction in ungauged arid and semi-arid region catchments based on morphological parameters and SCS curve number. J. Hydrol. 2012, 456, 94-100. [CrossRef]

64. Heimhuber, V.; Hannemann, J.-C.; Rieger, W. Flood Risk Management in Remote and Impoverished Areas-A Case Study of Onaville, Haiti. Water 2015, 7, 3832-3860. [CrossRef]

65. Surendra, K.M.; Vijay, P.S. Soil Conservation Service Curve Number (SCS-CN) Methodology; Springer: Berlin/Heidelberg, Germany, 2003.

66. Yan, B.; Fang, N.F.; Zhang, P.C.; Shi, Z.H. Impacts of land use change on watershed streamflow and sediment yield: An assessment using hydrologic modelling and partial least squares regression. J. Hydrol. 2013, 484, 26-37. [CrossRef]

67. Miller, S.N.; Kepner, W.G.; Mehaffey, M.H.; Hernandez, M.; Miller, R.C.; Goodrich, D.C.; Devonald, K.K.; Heggem, D.T.; Miller, W.P. Integrating Landscape Assessment and Hydrologic Modeling for Land Cover Change Analysis. J. Am. Water Resour. Assoc. 2002, 38, 915-929. [CrossRef]

68. Nie, W.; Yuan, Y.; Kepner, W.; Nash, M.S.; Jackson, M.; Erickson, C. Assessing impacts of Landuse and Landcover changes on hydrology for the upper San Pedro watershed. J. Hydrol. 2011, 407, 105-114. [CrossRef]

69. Wilk, J.; Hughes, D.A. Simulating the impacts of land-use and climate change on water resource availability for a large south Indian catchment. Hydrol. Sci. J. 2002, 47, 19-30. [CrossRef]

70. Zhou, S.; Zhang, W.; Guo, Y. Impacts of Climate and Land-Use Changes on the Hydrological Processes in the Amur River Basin. Water 2019, 12, 76. [CrossRef]

71. Li, R.; Min, Q. Dynamic response of microwave land surface properties to precipitation in Amazon rainforest. Remote. Sens. Environ. 2013, 133, 183-192. [CrossRef]

72. Gwate, O.; Woyessa, Y.E.; Wiberg, D. Dynamics of Land Cover and Impact on Stream flow in the Modder River Basin of South Africa: Case Study of a Quaternary Catchment. Int. J. Environ. Prot. Policy 2015, 3, 31-38. [CrossRef]

73. Wu, J.; Miao, C.; Wang, Y.; Duan, Q.; Zhang, X. Contribution analysis of the long-term changes in seasonal runoff on the Loess Plateau, China, using eight Budyko-based methods. J. Hydrol. 2017, 545, 263-275. [CrossRef]

74. Zuo, D.; Xu, Z.; Yao, W.; Jin, S.; Xiao, P.; Ran, D. Assessing the effects of changes in land use and climate on runoff and sediment yields from a watershed in the Loess Plateau of China. Sci. Total. Environ. 2016, 544, 238-250. [CrossRef]

75. Fahey, B.; Payne, J. The Glendhu experimental catchment study, upland east Otago, New Zealand: 34 years of hydrological observations on the afforestation of tussock grasslands. Hydrol. Process. 2017, 31, 2921-2934. [CrossRef]

76. Glavan, M.; Bele, S.; Curk, M.; Pintar, M. Modelling Impacts of a Municipal Spatial Plan of Land-Use Changes on Surface Water Quality-Example from Goriška Brda in Slovenia. Water 2020, 12, 189. [CrossRef]

77. Langat, P.K.; Kumar, L.; Koech, R. Understanding water and land use within Tana and Athi River Basins in Kenya: Opportunities for improvement. Sustain. Water Resour. Manag. 2018, 5, 977-987. [CrossRef]

78. Kim, H.W.; Kim, J.-H.; Li, W.; Yang, P.; Cao, Y. Exploring the impact of green space health on runoff reduction using NDVI. Urban For. Urban Green. 2017, 28, 81-87. [CrossRef]

79. van Meerveld, H.J.; Zhang, J.; Tripoli, R.; Bruijnzeel, L.A. Effects of Reforestation of a Degraded Imperata Grassland on Dominant Flow Pathways and Streamflow Responses in Leyte, the Philippines. Water Resour. Res. 2019, 55, 4128-4148. [CrossRef] 
80. Bodoque, J.M.; Díez-Herrero, A.; Cortés, B.; Olcina, J.; García, J.A.; Ballesteros-Cánovas, J.A.; Amérigo, M. Improvement of resilience of urban areas by integrating social perception in flash-flood risk management. J. Hydrol. 2016, 541, 665-676. [CrossRef]

81. Candela, L.; Tamoh, K.; Olivares, G.; Gomez, M. Modelling impacts of climate change on water resources in ungauged and data-scarce watersheds. Application to the Siurana catchment (NE Spain). Sci. Total. Environ. 2012, 440, 253-260. [CrossRef]

82. Młyński, D.; Wałęga, A.; Stachura, T.; Kaczor, G. A New Empirical Approach to Calculating Flood Frequency in Ungauged Catchments: A Case Study of the Upper Vistula Basin, Poland. Water 2019, 11, 601. [CrossRef]

(C) 2020 by the authors. Licensee MDPI, Basel, Switzerland. This article is an open access article distributed under the terms and conditions of the Creative Commons Attribution (CC BY) license (http://creativecommons.org/licenses/by/4.0/). 